\title{
A ECONOMIA DO CINEMA NO MUNDO
}

Elder P. Maia Alves Professor do Instituto de Ciências Sociais e do Programa de Pós-Graduação em Sociologia Universidade Federal de Alagoas (ICS/PPGS/UFAL), Maceió, AL, Brasil.

Wanderson Gomes Mestre em sociologia, Universidade Federal de Alagoas (ICS/PPGS/UFAL), Maceió, AL, Brasil.

Ana Virgínia Cardoso Mestre em sociologia, Universidade Federal de Alagoas (ICS/PPGS/UFAL), Maceió, AL, Brasil.

Selefe Gomes Neta Graduação em ciências sociais, Universidade Federal de Alagoas (ICS/PPGS/UFAL), Maceió, AL, Brasil.

\begin{abstract}
Resumo -Este trabalho busca apresentar uma descrição precisa e rigorosa da economia do cinema no mundo. Para tanto, explora três aspectos que definem os contornos geais dessa economia hoje: i) os impactos do processo de digitalização do simbólico sobre a diferenciação interna da economia do audiovisual; ii) os mecanismos de apoio e financiamento das empresas produtoras, distribuidora e exibidora de conteúdos cinematográficos, fortalecendo os mercados nacionais em diversos lugares do globo e, por conseguinte, acentuando a competição; iii) a relevância econômica do Fundo Setorial do Audiovisual (FSA) para o fortalecimento do mercados de conteúdos cinematográficos brasileiros, estabelecendo um ecossistema inédito de financiamento das empresas brasileiras.
\end{abstract}

Palavras chave: Audiovisual; Cinema; Economia.

\section{THE ECONOMICS OF CINEMA IN THE WORLD}

\begin{abstract}
This paper seeks to present a precise and accurate description of the world cinema economy. To do so, it explores three aspects that define the geographic contours of this economy today: i) the impacts of the digitalization process of the symbolic on the internal differentiation of the audiovisual economy; (ii) mechanisms to support and finance the production, distribution and display companies of cinematographic content, strengthening national markets in various parts of the world and, consequently, enhancing competition; iii) the economic relevance of the Audiovisual Sectorial Fund (FSA) for the strengthening of the markets of Brazilian cinematographic contents, establishing an unprecedented ecosystem of financing of Brazilian companies.
\end{abstract}

Keywords: Audiovisual; Cinema; Economy.

\section{INTRODUÇÃO}

O mundo vive intensamente a cultura das telas - telas de cinema, telas de televisores, telas de computadores, talas de tablets e, principalmente, as telas dos smartphones. Todas essas telas estão hoje conectadas e inter-relacionadas. A maioria dos aparelhos de televisão fabricados em 2017 já foram smart TVs - televisões que dispõem da tecnologia que permite o acesso à internet. Todas as smart TVs fabricadas pela empresa sul-coreana Samsung (líder mundial do segmento com $41 \%$ de participação de mercado) já contém os aplicativos da 
Netflix, assim como do Youtube, maior canal de conteúdo audiovisual digital do mundo. Parte significativas dos filmes e séries antes produzidos para o cinema e para a televisão já são lançadas e exibidas simultaneamente nos dispositivos digitais móveis, como computadores, tablets e smartphones. A maioria dos conteúdos dos principais gêneros audiovisuais (longa-metragem de ficção, documentários, séries, telefilmes, web filmes, animação e videogames) já são lançados para ser exibidos nos múltiplos suportes e suas diferentes telas - são os chamados conteúdos multitelares.

$\mathrm{O}$ arranjo de processos econômicos que compõe a economia do cinema se inscreve em um escopo mais abrangente: a economia do audiovisual. A economia do audiovisual tornou-se um setor estratégico para a economia contemporânea. Trata-se de um dos segmentos que mais gera monetização, inovação, direitos autorais, capital humano, competitividade, oportunidades econômicas, trabalho, emprego e renda. A economia do audiovisual é hoje uma esfera que reúne muitas oportunidades estratégicas de desenvolvimento regional, contribuindo diretamente para a inclusão produtiva, a expansão de oportunidades e a valorização artístico-cultural de cidades, territórios e regiões. Diante dessa configuração, especialmente nos últimos dez anos, muitos governos nacionais, tanto dos países desenvolvidos quantos dos países em desenvolvimento, passaram a destinar recursos financeiros com vistas a aumentar a competitividade das suas empresas produtoras, distribuidoras e exibidoras de conteúdos nacionais que atuam nos mercados nacionais e no mercado global de um modo geral.

De acordo com a publicação Global Entrertainment e Media, o grande setor global de mídia e entretenimento arrecadou, em 2016, a soma de US\$1,8 trilhão, e tem a expectativa de elevar essa quantia para US\$2,23 trilhões, em 2021. O Brasil é o pais da América Latina que gera mais receita nesse grande segmento. Em 2016, o país gerou US\$ 35 bilhões em receitas, com projeção de gerar, em 2021, o montante de US\$ 42 bilhões. O setor global de mídia e entretenimento está diretamente ligado ao setor da economia criativa e/ou indústrias criativas. Definida pela Conferência das Nações Unidas sobre Comércio e Desenvolvimento (UNCTADIONU) como uma atividade econômica que abarca todos os bens e serviços que usam a criatividade como recurso intelectual e insumo primário imprescindível (como vídeo, música, programa de computadores, jogos digitais, moda, gastronomia, publicidade, livros, design, teatro, espetáculos, arquitetura, entre outros), a economia criativa contém em seu interior a economia do audiovisual. Em 2016, a economia criativa foi responsável por 8\% do Produto Interno Bruto (PIB) global e por 2,6\% do PIB brasileiro (FIRJAN, 2016).

O setor do audiovisual é o maior e mais importante setor da economia criativa global, e, junto com o setor musical, é aquele que apresenta as maiores taxas de inovação tecnológica, digitalização e competitividade. Conforme a Agência Nacional de Cinema (ANCINE), em 
2014, as atividades econômicas presentes no âmbito do setor audiovisual brasileiro foram diretamente responsáveis pela geração do montante de $\mathrm{R} \$ 22,2$ bilhões na economia brasileira. $\mathrm{O}$ valor real adicionado pela economia do audiovisual à totalidade da economia brasileira cresceu bastante nos últimos anos. Em 2007 o valor adicionado foi de R 8,7 bilhões, chegou a R \$ 16,3 bilhões em 2011, e, em 2014, alcançou o volume de R \$ 22,2 bilhões; um crescimento real (já descontados a média da inflação) de 65,8\% em sete anos, o que corresponde a uma média anual de 9,4\% durante esse período. Tal crescimento foi bem superior à média global de todos os demais setores e segmentos da economia brasileira durante o período. Em 2013 o volume de R \$22,2 bilhões correspondeu a 0,54\% do PIB brasileiro, superior a setores como a indústria têxtil, a produção de componentes eletrônicos e de informática e a indústria de produtos farmacêuticos. De acordo com a ANCINE, a cada 1,00 R \$ investido em cinema no Brasil, obtém-se $\mathrm{R} \$ 2,90$ de receita direta de bilheteria e retorno de $\mathrm{R} \$ 3,70$, somando-se todos os efeitos indiretos.

A economia do audiovisual está dividida em seis grandes mercados: 1) o mercado da televisão aberta (composto por empresas privadas e públicas de televisão); 2) o mercado da televisão por assinatura (ou TV fechada); 3) o mercado de vídeo doméstico (CDs, DVDs e BluRay); 4) o mercado de videogames; 5) o mercado de cinema (cinema de tela grande ou cinema de shopping) e 6) o mercado de internet.

Figura 1 - Mercados que compõem a economia do audiovisual

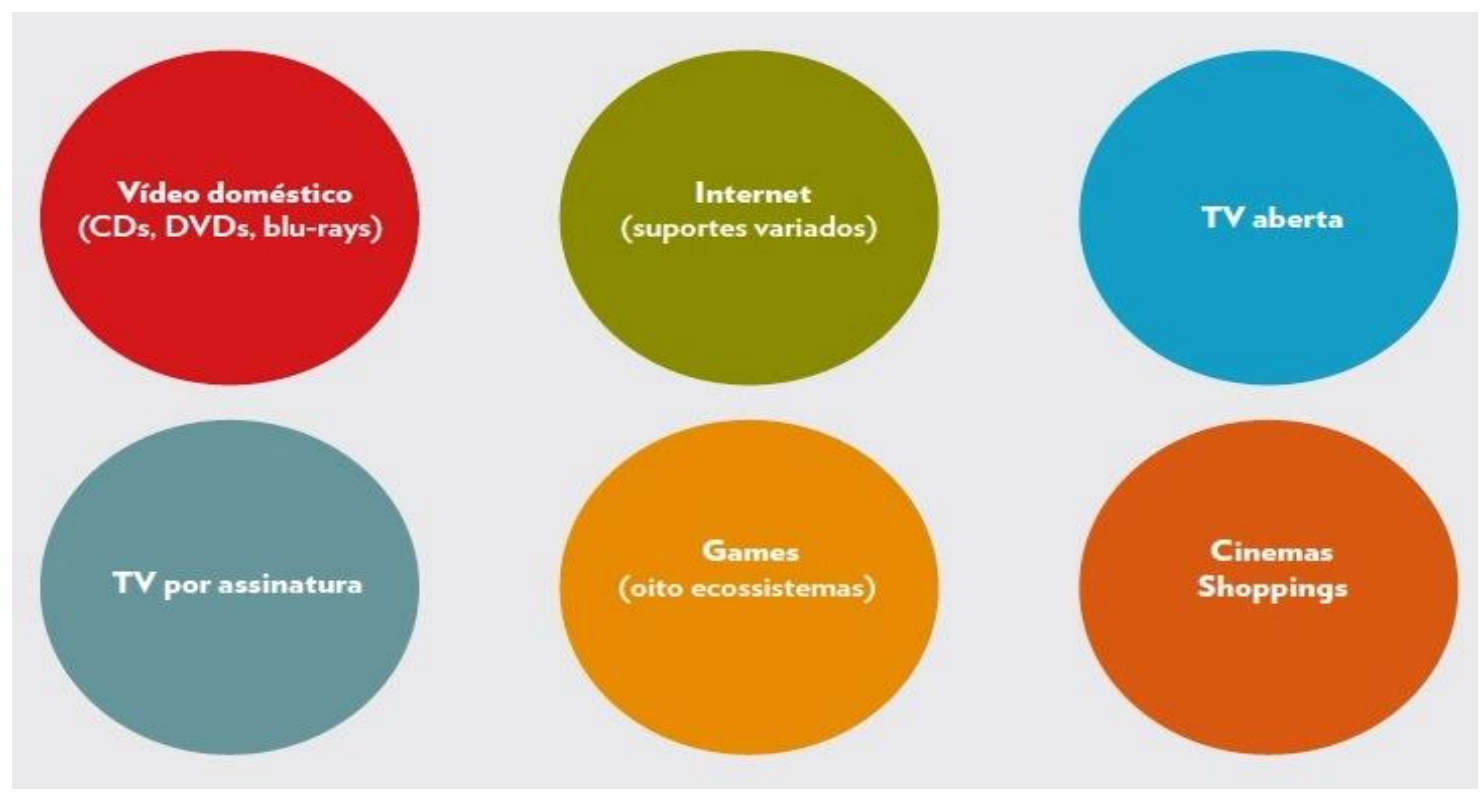

Fonte: Itaú Cultural, 2017.

Cada um dos mercados destacados na figura 1 apresentam características próprias, como as modalidades de tecnologia, o porte das empresas, os financiamentos governamentais, os canais de distribuição e os públicos consumidores. Neste trabalho tratarei apenas do 
mercado de cinema de tela grande (cinema shopping) e as suas interfaces com as políticas públicas de expansão e desenvolvimento nesse mercado em diferentes países do mundo. Além do mercado de cinema existe diversos outros mercados culturais: mercado musical, editorial, publicitário, de moda, design, de artes cênicas, de patrimônio cultural, entre outros. Os mercados culturais são divididos em dois critérios fundamentais: 1) os mercados culturais convencionais (offline) e 2) os mercados culturais digitais (online). No primeiro, predomina a criação, produção, distribuição e consumo de bens culturais; já no segundo predomina a criação, produção, distribuição e consumo dos serviços culturais-digitais.

A prática de consumo de um longa-metragem no cinema diz respeito ao consumo de um bem cultural; já a fruição de uma série ou um longa-metragem numa plataforma digital ondemand, ofertado por empresas como a Netflix, trata-se do consumo de um serviço culturaldigital. Do mesmo modo, a prática de consumo do conteúdo de um show musical refere-se ao consumo de um bem cultural; já a audição desse mesmo conteúdo musical nas plataformas musicais de streaming, como Spotify e Apple Music, transforma-se no consumo de um serviço cultural-digital. Tanto os mercados culturais convencionais (off-line) quanto os mercados culturais digitais (online) são compostos pelos seguintes agentes econômicos: 1) as empresas culturais privadas especializadas; 2) as empresas não culturais (ou empresas não especializadas); 3) os profissionais criativos especializados e trabalhadores da cultura; 4) os bancos comerciais privados; 5) as instituições estatais-governamentais; 6) os consumidores.

Figura 2 - Agentes econômicos que compõem os mercados culturais (off-line e online)

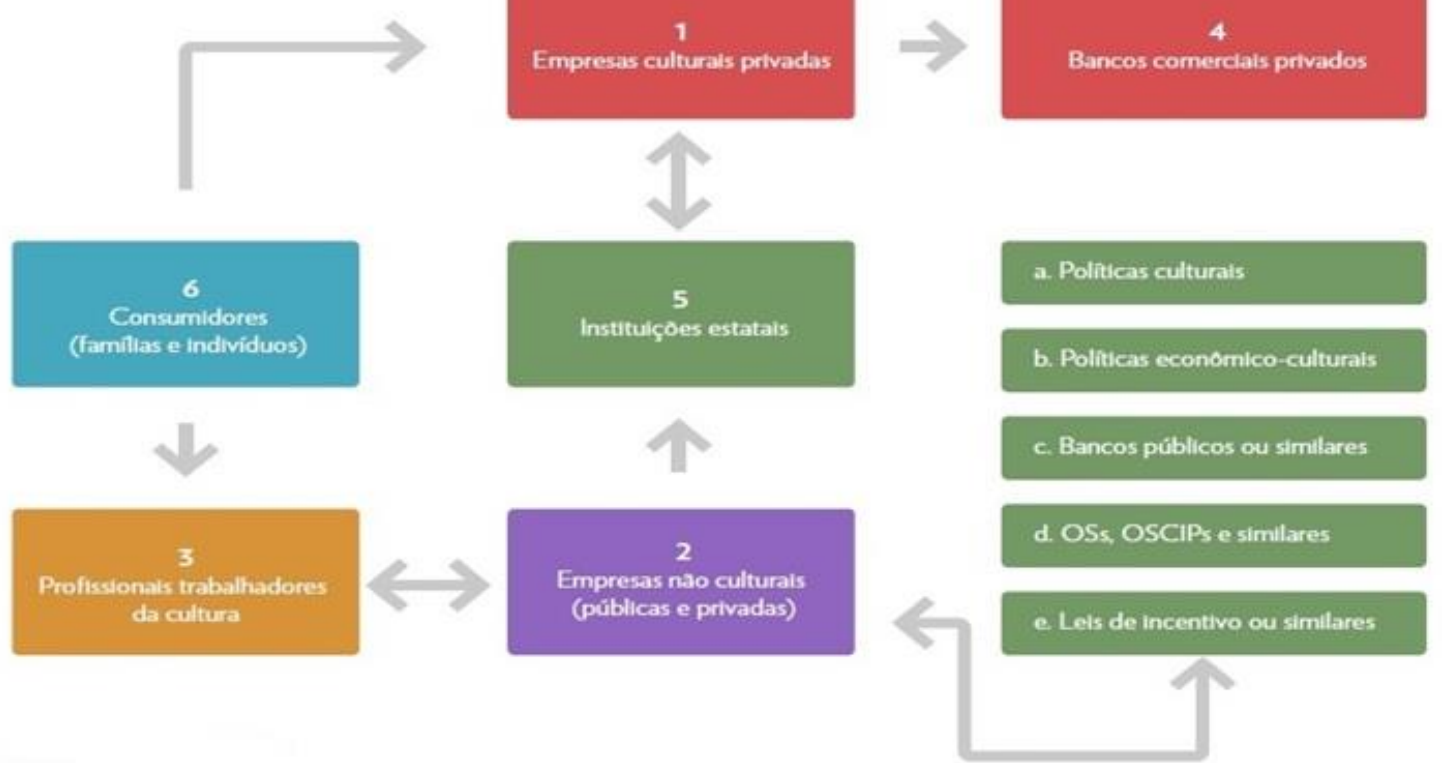

Fonte: Elaboração do autor. 
Os seis agentes econômicos apresentados na figura 2 interagem entre si e dependem, direta ou indiretamente, uns dos outros. Eles são os agentes econômicos que estão presentes em todo e qualquer mercado cultural, seja ele offline ou online, tanto no Brasil como em diversos países do mundo. No caso da economia do audiovisual, esses mesmo seis agentes também estão presentes nos quatro mercados mais promissores da economia contemporânea do audiovisual: i) cinema de tela grande; ii) TV por assinatura, iii) videogames e iv) internet.

Cada um dos agentes econômicos apresentados na figura 2 está presente em diferentes elos das cadeias produtivas. Por exemplo, no caso do mercado de cinema de tela grande (um mercado cultural offline) uma empresa de filmes, especializada na criação e produção de conteúdos (empresa cultural privada - primeiro agente) compete com outras empresas e integra o elo produção. Essa empresa possui uma quantidade de funcionários (profissionais e trabalhadores da cultura - terceiro agente) que também atuam no elo produção.

Já uma empresa especializada na distribuição de filmes (primeiro agente), que também possuía profissionais e trabalhadores - terceiro agente) compete com outras empresas de distribuição e atua no elo específico da distribuição. Por sua vez, uma empresa especializada na exibição de filmes (primeiro agente) também compete com outras empresas de exibição e também possui trabalhadores e profissionais e atua no elo de exibição. Essas três empresas (pessoas jurídicas) necessitam - umas mais e outras menos - de apoio (empréstimos direto, créditos fiscais, incentivos físcais, juros subsidiados, etc.) das organizações estatais (quinto agente da figura). Os governos atuam nos três elos: produção, distribuição e exibição. Já os consumidores (sexto agente da figura 2), que dispõem de distintos recursos econômicos, escolares e simbólicos, atuam no último elo, o consumo.

Figura 3 - Cadeia produtiva do mercado de cinema

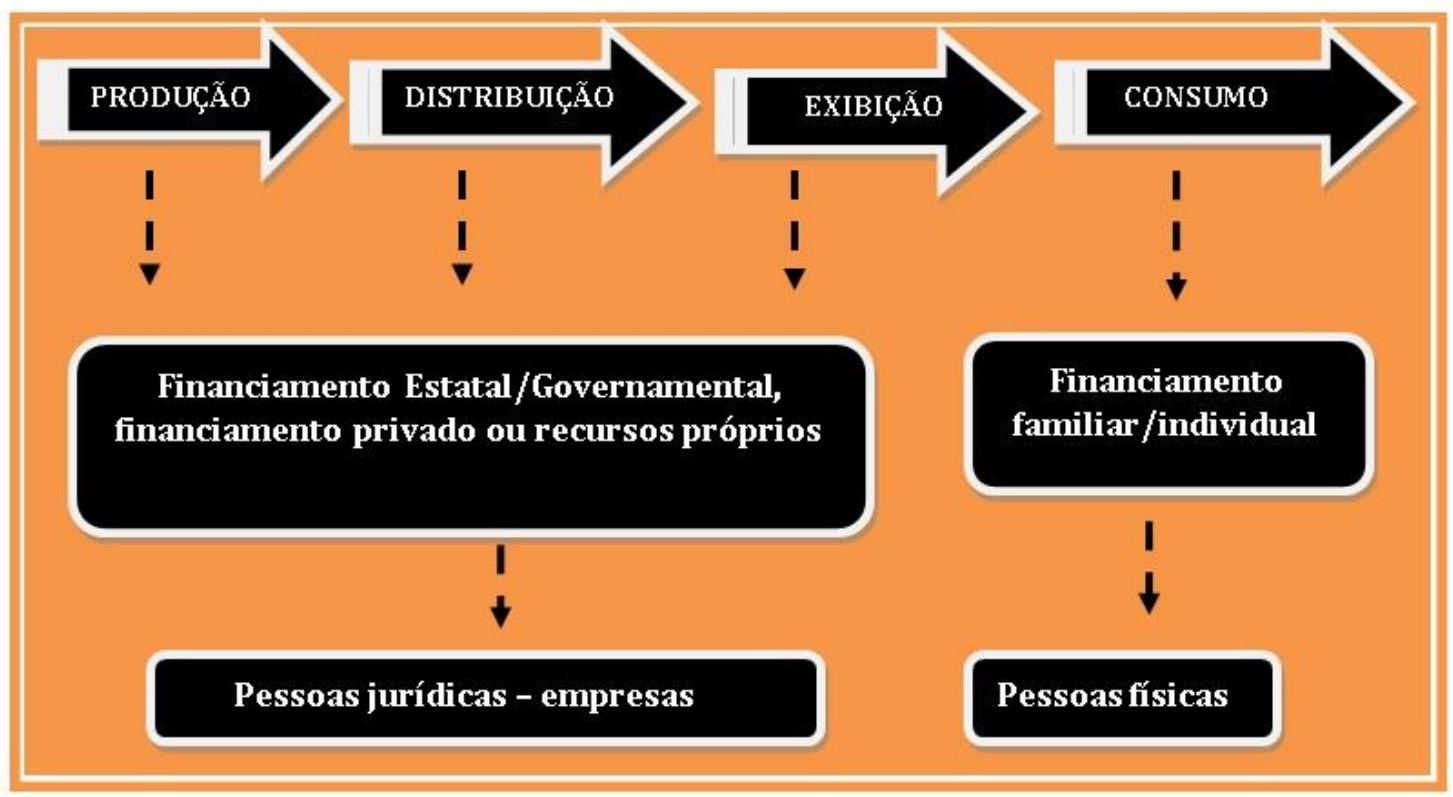

Fonte: elaboração própria. 
Para melhor delinear todos esses aspectos (economia, mercados, agentes econômicos e cadeias produtivas) podemos contar com o auxílio da figura 4. Na figura, são delineados a economia do audiovisual, os seus quatro mercados mais promissores e os seus respectivos agentes econômicos.

Figura 4 - Os mercados mais promissores da economia do audiovisual

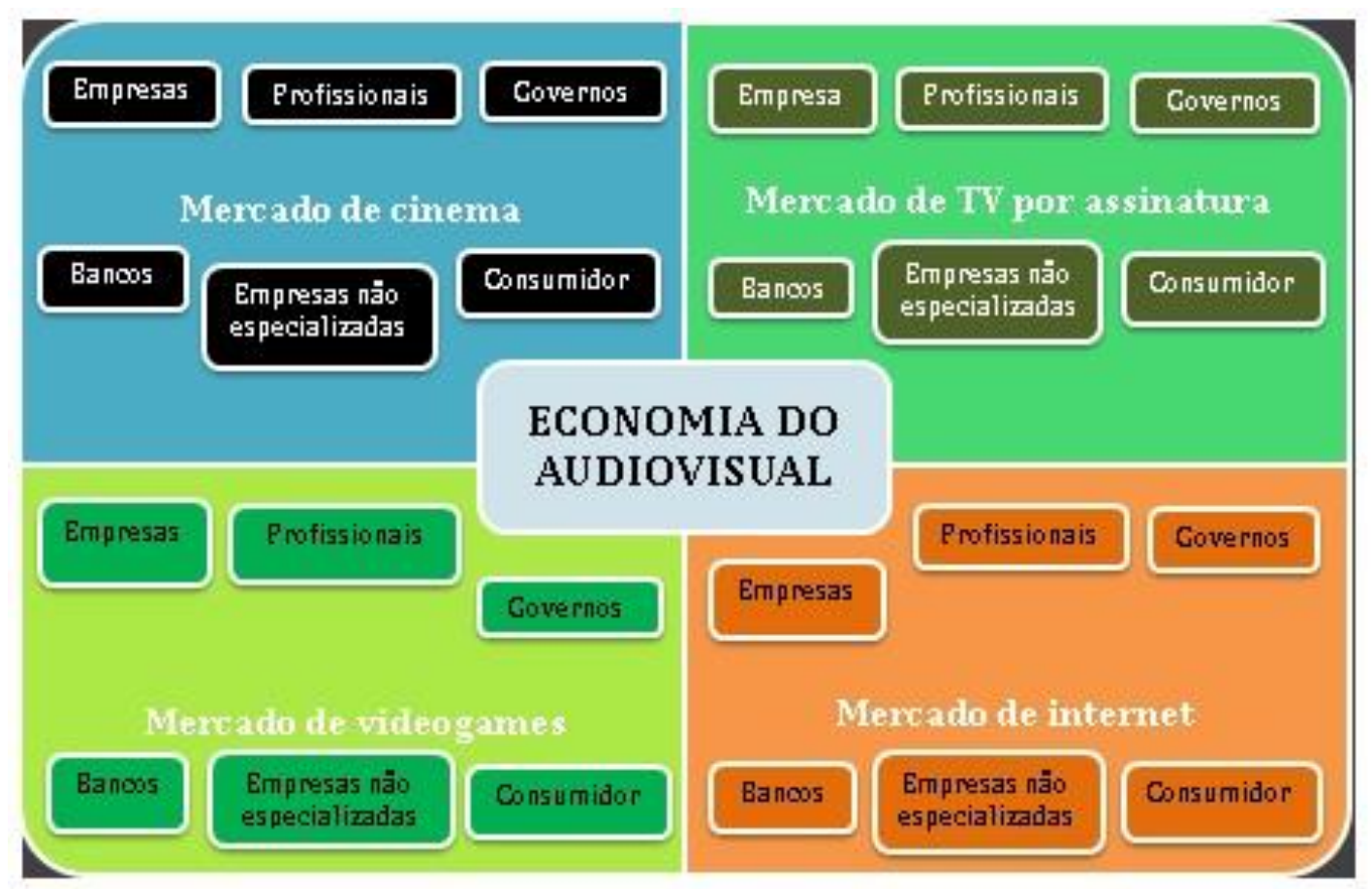

Fonte: elaboração própria.

Visando abordar a economia do cinema com a maior fidelidade empírica possível, e o maior rigor interpretativo, esse artigo está dividido em três partes complementares, além das considerações finais. A primeira trata das interfaces e interdependência dos mercados de cinema global com o processo de digitalização do simbólico. A segunda parte busca demonstrar as estratégias políticas e os impactos das políticas governamentais de investimento e desenvolvimentos dos mercados nacionais de cinema, acentuado a competição global. Já a terceira parte tenciona situar o Brasil nesse panorama, explorando os impactos econômicos do mais relevante ecossistema de financiamento para o mercado de conteúdos audiovisuais brasileiros, o Fundo Setorial do Audiovisual - FSA.

\section{A ECONOMIA DO CINEMA NO MUNDO E O PROCESSO DE DIGITALIZAÇÃO}

Não é possível compreender os labirintos econômicos da economia do audiovisual, em especial da economia do cinema, sem explorar, ainda que de modo bem breve, o processo de digitalização do simbólico. O processo de digitalização do simbólico abriga 
cinco fenômenos associados: 1) o intenso processo de aumento da velocidade, de armazenamento e transmissão de dados no âmbito da internet, materializado na tecnologia do streaming, que somente se tornou possível com o advento da computação em nuvem; 2) a profusão global dos dispositivos digitais móveis, notadamente os smartphones; 3) a convergência digital, que liga e conecta diversos dispositivos entre si, múltiplos suportes e linguagens, originando o fenômeno transmídia, inteiramente ligado à internet das coisas; 4) e o advento da internet 2.0, fase da internet na qual a maioria dos dados (textos, notícias, vídeos, músicas, mensagens, imagens, etc.), são criadas, compartilhadas e consumidas pelos próprios usuários, conectados e engajados nas principais redes sociais digitais globais, como Facebook, Instagram, WhatsApp, Youtube e Twitter, etc; 5) a expansão global dos usuários de internet, que chega a $80 \%$ das populações dos países desenvolvidos.

Em 2017, o Festival de Cinema de Cannes, pela primeira vez, selecionou dois filmes produzidos pela empresa norte-americana Netflix. A seleção de filmes disponíveis somente na internet, como é o caso dos filmes da Netflix, contrariou lei nacionais francesas, que permite apenas permite a disponibilização de filmes em plataformas de streaming (transmissão contínua) após decorridos três anos da exibição nas telas dos cinemas do pais. Esse aspecto gerou uma serie de negociação entre a Netflix, o governo francês e os organizadores do Festival de Cannes. Essas negociações e tensões entre a empresa norte-americana e muitos governos nacionais têm sido cada vez mais frequentes. Em 2018, a lista de indicados para o prêmio da Academia de Artes e Ciências da Televisão, o Emmy (equivalente ao Oscar) trouxe diversos conteúdos originais produzidos pela Netflix. A empresa obteve no total 112 indicações, superando canais de TV por assinaturas, como o tradicional HBO. Outros dois serviços de stremming de vídeo também obtiveram indicações, como Amazon Prime Video e Hulu.

Os mercados culturais produzem bens culturais, já os mercados culturais-digitais produzem serviços culturais-digitais. Há três aspectos estruturais que diferenciam os mercados culturais-digitais entre si e os diferenciam dos mercados culturais convencionais: a) o grau de inovação tecnológica, b) o grau de digitalização e c) o grau de convergência digital. O mercado audiovisual e o mercado musical (situado no topo da figura 6) são os mais digitalizados, os mais inovadores e com o maior grau de convergência digital. Significa que são os primeiros mercados quase inteiramente digitalizados, existindo tanto na forma convencional (offline), quanto na forma digital (online). Nos últimos dez anos essa foi uma transformação radical. Os mercados culturais, como demonstra a figura 5, estão em um estágio mais ou menos avançado de digitalização. No caso dos mercados mais relevantes que compõem a economia do audiovisual, todos apresentam um elevado estágio de digitalização. 
Quanto mais um mercado cultural convencional apresenta elevadas taxas de inovação tecnológica, digitalização e convergência digital tanto mais ele está ancorado e monetizado pela presença dos serviços culturais-digitais. É o caso do mercado musical, o mercado mais digitalizado do mundo. Em 2016, 50\% de todo faturamento do mercado fonográfico global foi gerado pela esfera digital, tendo os suportes físicos (CDs e DVDs) contribuído com $34 \%$ e as performances (shows) ao vivo correspondendo a 14\%. Esse é mercado com a maior presença dos serviços culturais-digitais, especialmente aqueles ofertados através de assinaturas digitais ancorados na tecnologia do streaming, liderados por plataformas como Spotfy, Apple Music e Dizeer. A figura 7 demonstra a expansão da digitalização dos conteúdos musicais no ano de 2016.

Figura 5 - Mercados culturais e digitalização dos conteúdos de arte e cultura

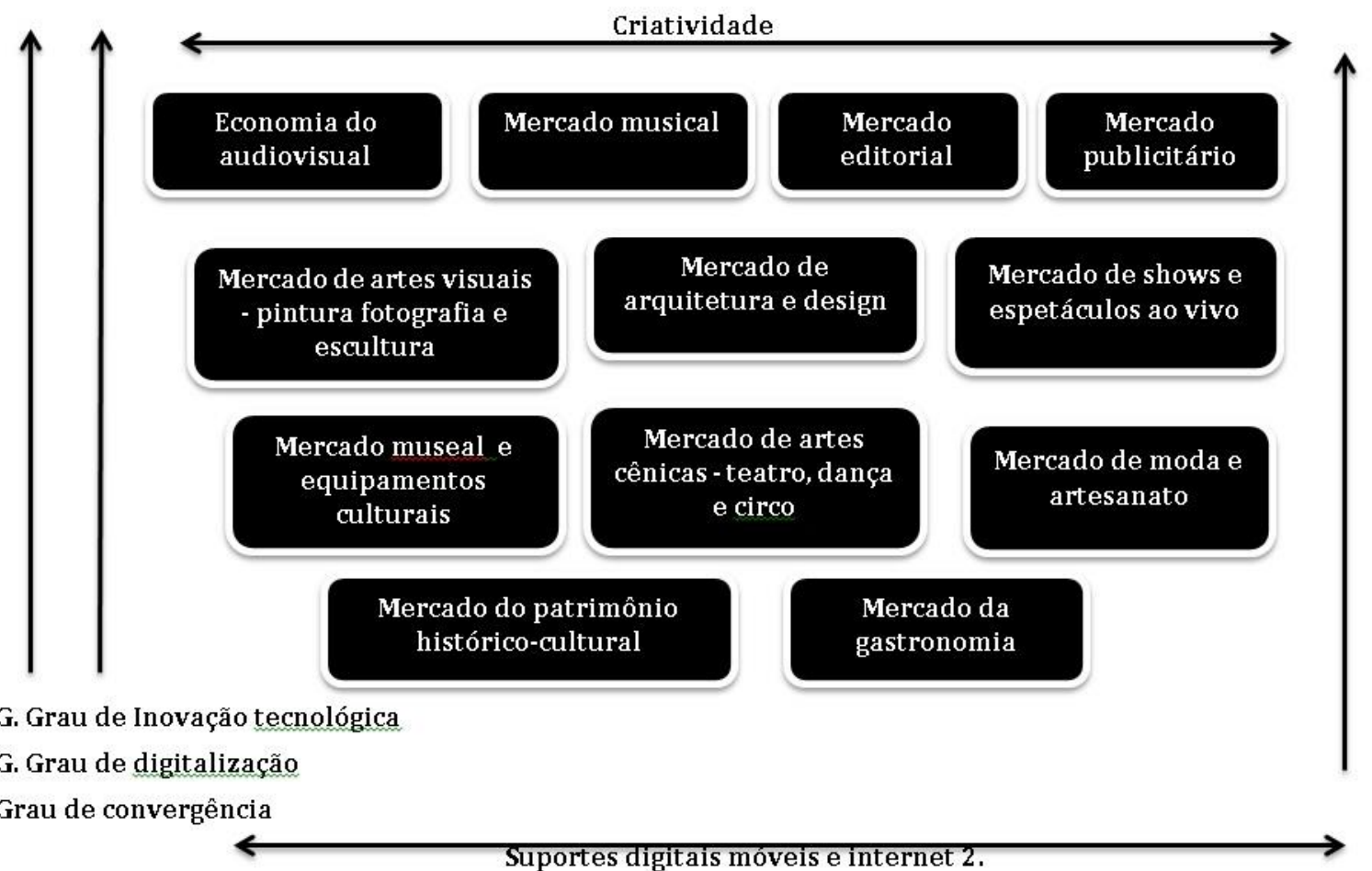

Fonte: elaboração do autor.

O intenso crescimento das plataformas online, como o Youtube e a Netflix, a partir do processo de digitalização pode, no curto e médio prazo, levar ao processo de "desintermediação" (anulação do papel do intermediador) e levar a uma superconcentração (UNESCO, 2018). O Youtube, por exemplo, que pertence ao Google, possui cerca de 900 milhões de usuários. Sua força dificulta o processo de negociação de preços por parte dos criadores de conteúdo ou proprietários dos direitos autorais, ao passo que permite que novos criadores disponibilizem seus conteúdos na plataforma. O Youtube paga, em média US\$1,00 por cada usuário que acessa determinado conteúdo. Por outro lado, plataformas especializadas em assinaturas mensais, como Spotify, que possui uma carteira de usuários infinitamente menor, paga US\$18,00 aos criadores e/ou aos detentores dos direitos autorais por cada 
usuário que acesse determinado conteúdo. Essa discrepância acaba gerando receita muito distintas para os criadores/proprietários dos direitos autorais, pois os modelos de negócios são muito distintos, uma vez que o Youtube não cobra diretamente pelo acesso ao conteúdo audiovisual, obtendo sua receita através de anúncios e mensagens publicitárias. $\mathrm{O}$ retorno financeiro para os criadores e/ou detentores dos direitos autorais é muito maior junto aos serviços de assinatura via streaming, embora esses tenham uma base de usuários muito menor.

Gráfico 1 - Discrepância no valor no streaming

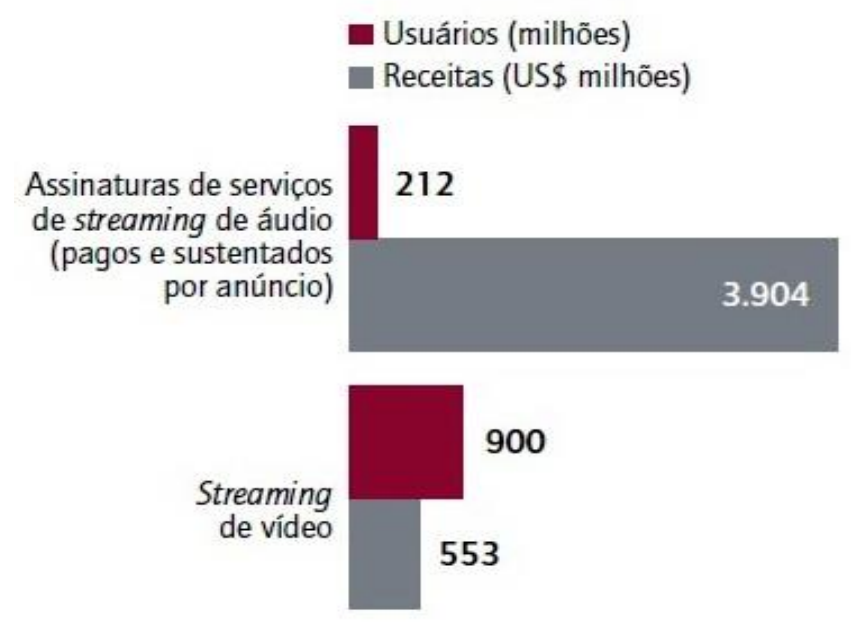

Fonte: UNESCO, 2018.

Como as principais empresas e plataformas que produzem, distribuem e licenciam os serviços culturais-digitais estão sediadas nos EUA. Os EUA se tornaram o maior exportador de serviços culturais-digitais do globo, cujo valor total (US\$ 68,6 bilhões, em 2013) foi superior ao somatório de todos os 14 maiores exportadores juntos (UNESCO, 2015).

Gráfico 2 - Balança comercial de serviços culturais-digitais para países selecionados, 2013.

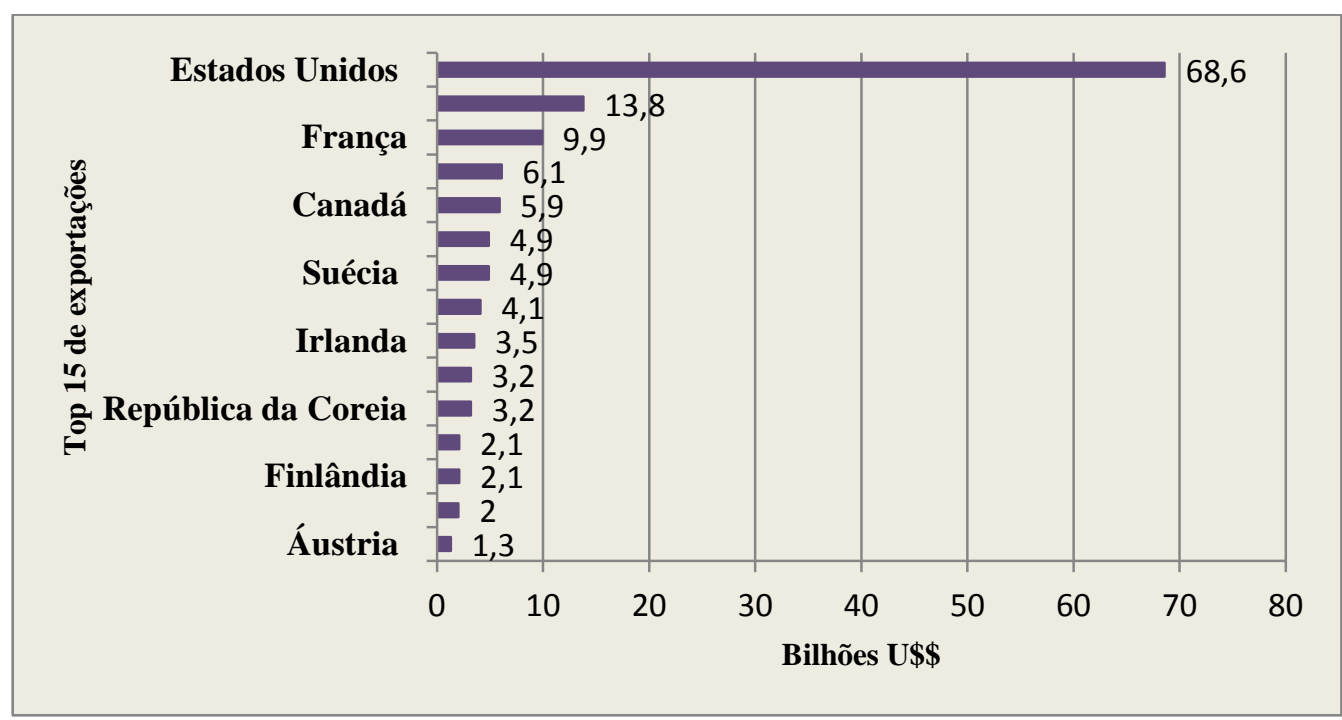

Fonte: UNESCO, 2016. 


\section{O MERCADO DE CINEMA NO MUNDO: INVESTIMENTOS GOVERNAMENTAIS E COMPETIÇÃO GLOBAL}

Em 2014 o valor total das exportações dos bens culturais (amparados nos suportes físicos, como DVDs, CDs, livros, quadros, telas, etc.) alcançou o volume de US\$ 252,2 bilhões, um crescimento de $20 \%$ em comparação ao ano anterior. Tendo em vista a importância estratégica do setor do audiovisual, dos bens culturais e dos serviços culturais-digitais como um todo, muitos países em desenvolvimento, especialmente China e Índia, se lançaram na competição global para controlar os seus próprios mercados audiovisuais e conquistar mercados estrangeiros.

Em 2005, os países em desenvolvimento respondiam por $25 \%$ do total do fluxo (exportações e importações) comercial global de bens culturais, percentual que subiu para $45 \%$ em 2014. Nesse mesmo ano, pela primeira vez, as exportações de todos os países em desenvolvimento superaram os países desenvolvidos, alcançando 52,6\%.

No entanto, esse feito somente foi alcançado pelo destaque assumido por China e Índia, cujos governos nacionais desde o início do século XXI passaram a investir na produção e exportação de bens culturais, especialmente o audiovisual.

Gráfico 3 - Influência da Índia e da China nas exportações de bens culturais, 2005-2015.

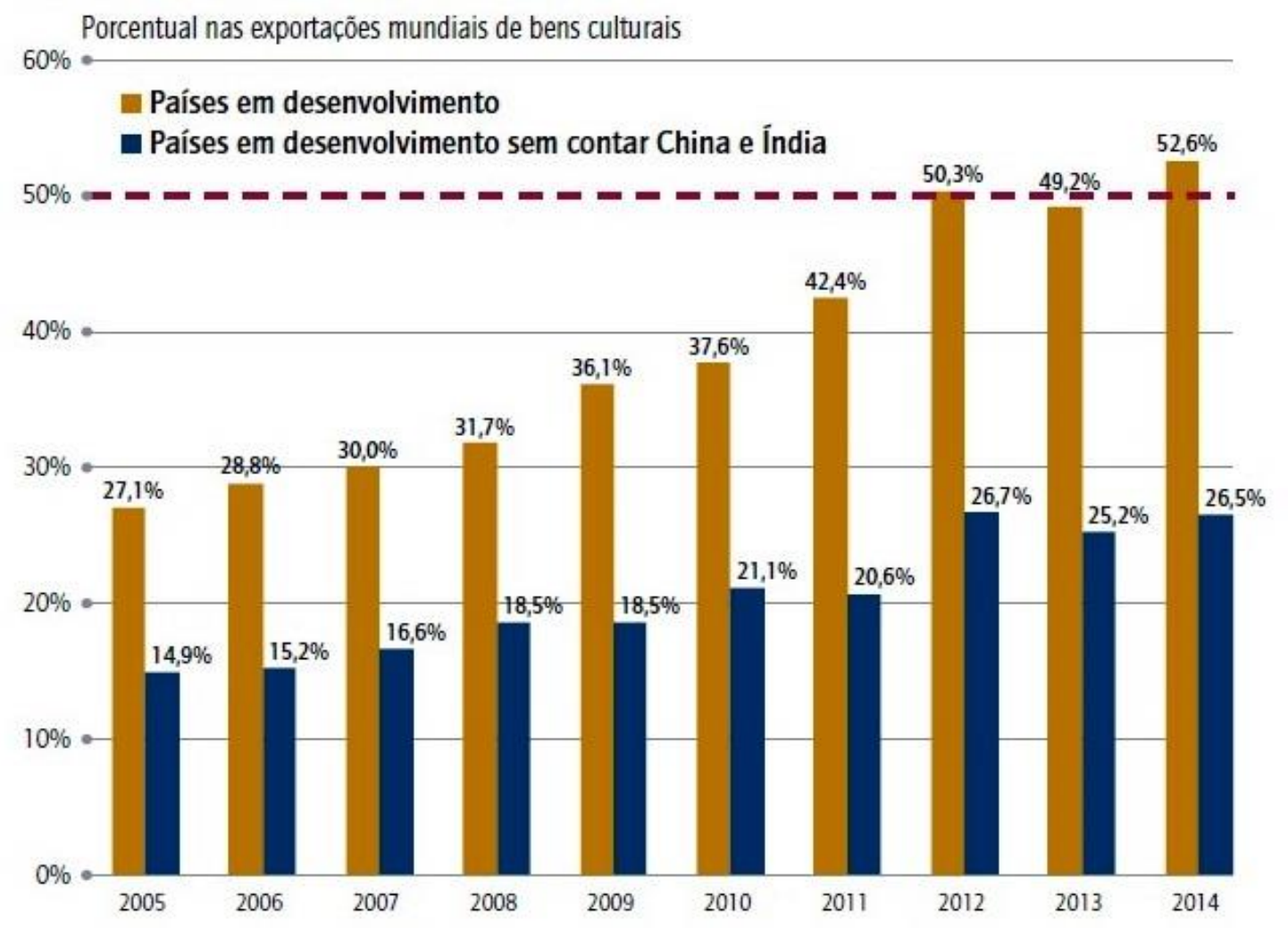

Fonte: UNESCO, 2018. 
Se China e Índia forem retiradas desse computo, as exportações de bens culturais dos países menos desenvolvidos (PMD) recuam para 26,5\%, em 2015. Mesmo retirando-se China e Índia, entre 2005 e 2015 ocorreu um aumento nas exportações de bens culturais dos países menos desenvolvidos (PMD), saindo de 15\%, em 2005, para 26,5\%, em 2015 (UNESCO, 2018). Se esses dados forem desagregados por setores, tem-se um quadro um pouco mais complexo. Essa desagregação pode ser feita a partir dos chamados bens culturais essenciais (audiovisual e música, edição e artes visuais). Em 2005, o total das exportações dos setores de audiovisual e musical por parte dos países em desenvolvimento alcançou 15,4\% do comércio global. Em 2015, esse mesmo percentual chegou a 23,3\% do comércio global. Mesmo com esse crescimento, o ritmo da expansão diminuiu.

A participação total (o fluxo de exportação e importação) do comércio de bens audiovisuais e musicais diminuiu acentuadamente entre 2005 e 2015. Nesse intervalo ocorreu uma redução de $28 \%$ nas exportações de bens audiovisuais e musicais, saindo de US\$ 29,4 bilhões, em 2005, para US\$ 21,2 bilhões, em 2014. Isso não significa que ocorreu uma redução na produção, distribuição e consumo dos conteúdos audiovisuais e musicais, pelo contrário. O que ocorreu foi um intenso processo de digitalização desses conteúdos, cujos mercados, o audiovisual e o musical, são os que apresentam as maiores taxas de inovação tecnológica, o maior processo de convergência digital e de digitalização e, como consequência, as maiores transformações nos modelos de negócios praticados.

O mercado de cinema mundial é o mais antigo e globalizado dos mercados que compõem a economia do audiovisual. Em 2016 a arrecadação derivada da venda de ingressos alcançou um novo record no mundo, ultrapassando a marca de US\$ 38 bilhões. Desde os anos de 1920 os EUA montaram o maior polo cinematográfica do mundo, sediada em Hollwood, Califórnia, concentrada em seis grandes estúdios de cinema: Warner Bros, Fox, Universal, Disney, Paramount/Sony e Columbia.Logo após a Segunda Guerra Mundial,o Departamento de Estado dos EUA, por meio da sua Secretaria de Comércio Exterior, passou a influenciar seus principais parceiros comerciais e aliados militares a permitir, sem restrições, o ingressodos filmes norte-americanos nos seus respectivos mercados. A atuação da Secretaria de Comércio Exterior do Departamento de Estado dos EUA ocorre em duas frentes. A primeira se dedica a fazer com que os governos nacionais reconheçam e adotem as leis norte-americanas de propriedade intelectual. A segunda consiste em dissuadir os parceiros comerciais (como o Brasil e os membros da União Europeia) de adotar políticas de fomento e financiamento dos conteúdos cinematográficos nacionais e locais.

Nos últimos dez anos, a atuação da Secretaria de Comércio Exterior do Departamento de Estado se intensificou ainda mais, pois o pêndulo da relação entre consumo nacional e internacional se inverteu. No final do século XX, $60 \%$ de todo o faturamento dos filmes 
produzidos nos EUA advinha dos ingressos vendidos no próprio EUA; dez anos mais tarde esse porcentual se inverteu. Em 2007, a quantia global de ingressos vendidos para os filmes norte-americanos totalizou US\$ 26,7 bilhões; desse montante US\$ 17,1 bilhões vieram de ingressos vendidos no exterior, o que representou 63\% do total (MPAA, 2007). Essa dependência da produção dos EUA junto aos mercados internacionais acirrou a competição no mercado cinematográfico global.

Somados, em 2009, os seis mercados que compõem a economia do audiovisual (TV aberta, TV por assinatura, vídeo doméstico, cinema de tela grande, videogame e internet) adicionaram à economia dos EUA o valor total de US\$1,104 trilhão - cerca de $8 \%$ do PIB da maior economia do planeta. A criação e os serviços de entretenimento, encabeçados pelo cinema, já ocupavam a segunda posição na pauta de exportações dos EUA no final do século $\mathrm{XX}$, superada apenas pelo segmento de componentes aeroespaciais.

Durante os primeiros anos do século XXI, essa posição se consolidou, tornando as exportações dos conteúdos cinematográfico ainda mais estratégico para o saldo da balança comercial dos EUA. Entre 2004 e 2008, a venda dos ingressos internacionais dos filmes produzidos nos EUA cresceu 17\%. Esses filmes alcançaram um total de 105 países, mas apenas oito deles respondem por aproximadamente $75 \%$ da renda dos filmes norte-americanos fora dos EUA.

Tabela 1 - Faturamento dos filmes produzidos nos EUA nos principais mercados internacionais -2015 .

\begin{tabular}{|c|c|}
\hline Pais & Faturamento (em US\$) \\
\hline China & 2,7 bilhões \\
\hline Japão & 2,4 bilhões \\
\hline Reino Unido & 1,7 bilhões \\
\hline Alemanha & 1,6 bilhões \\
\hline Espanha & 1,5 bilhões \\
\hline Itália & 1,4 bilhões \\
\hline França & 1,3 bilhões \\
\hline Austrália & 1,2 bilhões \\
\hline Total & 13,8 bilhões \\
\hline
\end{tabular}

Fonte: ANCINE, 2016.

Em 2007 o filme o Homem Aranha 3 (um dos maiores orçamentos já registrados), do estúdio Sony, por exemplo, obteve uma renda global de US\$ 890 milhões, sendo US\$ 336 milhões $(37,8 \%$ do total da receita) no próprio mercado doméstico norte-americano (EUA e Canadá) e US\$ 554 milhões (62,2\% da receita) em âmbito internacional. O Homem Aranha 3 registrou um custo total de US\$ 380 milhões. Desses, nada menos do que US\$ 120 milhões foram destinados ao marketing internacional do filme, ou seja, $32 \%$ do custo total da obra. 
Essa não foi uma exceção, pois, cada vez mais, os custos/investimentos em marketing se aproximam de $50 \%$ do orçamento geral dos filmes criados e produzidos nos EUA (os chamados filmes mainstreamou, mais especificamente, osblocsbuster).

Entre os anos de 2008 e 2014, dos 20 filmes mais vistos no globo, todos foram produzidos ou coproduzidos pelas corporações audiovisuais norte-americanas. Conforme a Conferência das Nações Unidas sobre o Comércio e Desenvolvimento (UNCTAD), em 2013 cerca 80\% de todos os filmes consumidos no mundo foram produzidos por seis grandes conglomerados norte-americanos: Warner Bros, Fox, Universal, Disney, Paramount/Sony e Columbia. Segundo Stigler, essas companhias forjam os oligopólios de franja, que consiste no controle do processo de financiamento - atuando de maneira semelhante a um banco. Essas empresas delegam as etapas de criação, produção, distribuição e licenciamento a um conjunto de outras empresas (micro, pequenas e médias), que ficam sob sua coordenação e seu domínio direto ou indireto.

Além de gerar receitas e lucros para as empresas dos EUA, o cinema gera milhares de empregos para os trabalhadores e profissionais criativos do cinema nos EUA. Entre 2013 e 2017 os EUA produziram, por ano, uma média de 650 filmes, que movimentaram uma média anual de US\$ 120 bilhões e geraram aproximadamente 210 mil empregos diretos por ano. Trata-se de um forte e concorrido mercado de trabalho, cujas profissões (roteirista, iluminador, cenógrafo, fotógrafo, figurinista, diretor, ator, músico, pesquisador, etc.) estão bastante presentes nas universidades e escolas técnicas especializadas. Em 2017, de todos os países da Europa e da América do Norte $76 \%$ abrigavam pelo menos uma escola de cinema, ao passo que, de todos os países da América Latina e Caribe, $40 \%$ abrigavam ao menos uma escola de cinema.

Gráfico 4 - Percentual de países com pelo menos uma escola de cinema, por região, 2017

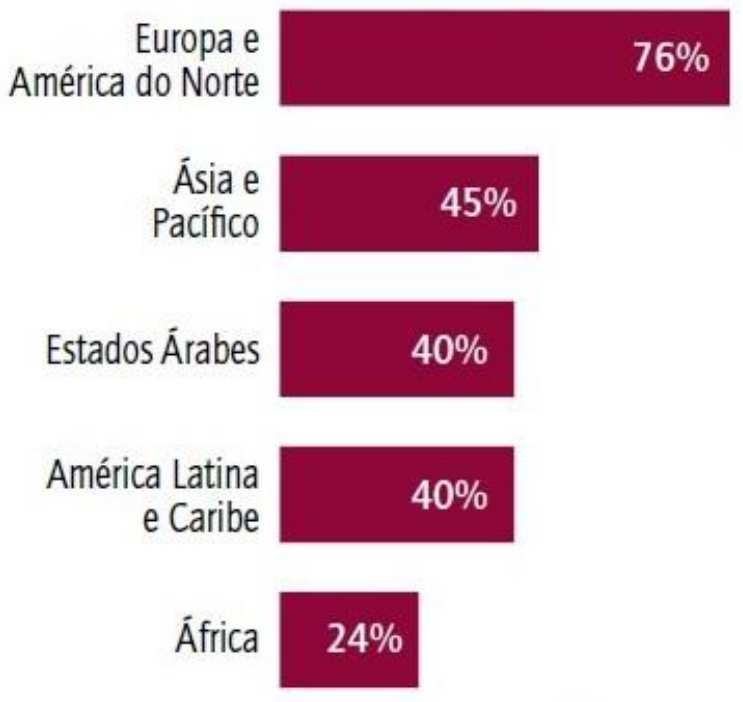

Fonte: UNESCO, 2018. 
Entre 2005 e 2017 a produção de filmes no mundo aumentou em 64\%. Os governos de todo o mundo, seguindo o exemplo dos EUA, passaram a investir em políticas de financiamento de conteúdos cinematográficos nacionais e locais. Essas políticas visam obter dois objetivos: 1) proteger os seus mercados nacionais da penetração dos filmes estrangeiros, especialmente dos filmes criados, produzidos e distribuídos pelas empresas dos EUA, e 2) gerar trabalho, emprego e renda para os profissionais locais por meio do aumento da criação, da produção, da distribuição e do consumo dos conteúdos nacionais e locais.

Como demonstra a tabela 3, em 2017 a participação do público doméstico nos títulos nacionais é muito assimétrica. O público nacional consome quase a totalidade dos títulos nacionais nos EUA. Já no Japão, China e Rússia a participação dos títulos nacionais junto ao total do público está acima dos 30\%. Esses são os países que recentemente têm obtido mais êxito na proteção dos seus mercados contra os títulos estrangeiros, notadamente aqueles produzidos nos EUA. Rússia, Alemanha, Espanha, Argentina e Brasil têm lutado para competir, com certo poder, com os títulos estrangeiros em seus mercados doméstico. O terceiro grupo, composto por México, Colômbia, Austrália, Portugal e Chile, tem seu mercado doméstico quase inteiramente dominado pelos títulos estrangeiros.

Tabela 3 - Participação de público dos títulos nacionais em países selecionados (2017)

\begin{tabular}{c|c|c} 
Pais* & Participação & $\begin{array}{c}\text { Público Títulos Nacionais } \\
\text { (em milhöes) }\end{array}$ \\
\hline EUA & $92,1 \%$ & $1.120,6$ \\
\hline Japão & $54,9 \%$ & 95,8 \\
\hline China & $53,8 \%$ & 871,6 \\
\hline França & $37,4 \%$ & 78,3 \\
\hline Rússia & $24,1 \%$ & 51,1 \\
\hline Alemanha & $23,9 \%$ & 29,2 \\
\hline Espanha & $17,0 \%$ & 17,0 \\
\hline Argentina & $13,2 \%$ & 6,5 \\
\hline Brasil & $9,6 \%$ & 17,4 \\
\hline México & $7,0 \%$ & 23,7 \\
\hline Colômbia & $5,9 \%$ & 3,7 \\
\hline Australia & $4,1 \%$ & 3,5 \\
\hline Portugal & $2,6 \%$ & 0,4 \\
\hline Chile & $0,7 \%$ & 0,2
\end{tabular}

Fonte: ANCINE, 2018.

A disputa por novos e antigos mercados, internos e externos, elevou bastante a competição no mercado cinematográfico global. 92\% dos países da Europa e da América do Norte investem regularmente na produção cinematográfica nacional, enquanto na América Latina e Caribe esse percentual cai para $46 \%$. Os 25 principais produtores de cinema do mundo 
mantem fundos públicos nacionais (como o Fundo Setorial do Audiovisual, no Brasil), regionais e locais destinados à produção dos conteúdos cinematográficos.

Entre os países desenvolvidos, $70 \%$ mantem fundos públicos nacionais, 23\% mantém fundos públicos nacionais e regionais e $8 \%$ mantém apenas fundos regionais. Já entre os países em desenvolvimento, $86 \%$ mantém fundos públicos nacionais, $6 \%$ fundos nacionais e regionais e $8 \%$ fundos apenas regionais.

Gráfico 5 - Percentual de países que investem regularmente na produção cinematográfica nacional, por região, 2017.

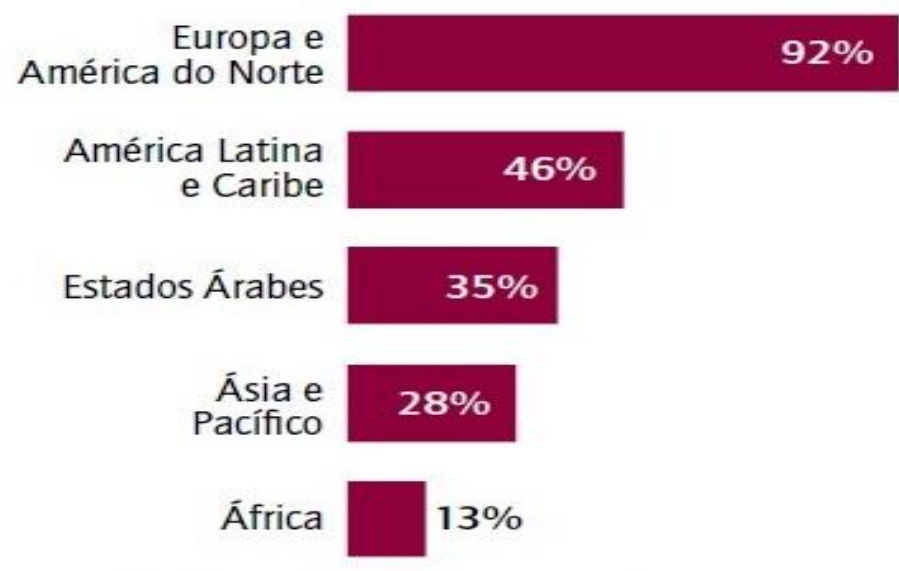

Fonte: UNESCO, 2018.

O gráfico 6 evidencia a relevância econômica estratégica que o cinema assumiu para os governos da maioria dos países desenvolvidos e em desenvolvimento. Dos 25 maiores produtores mundiais de filmes de longa-metragem, apenas Indonésia, Irã e Malásia (países em desenvolvimento) não possuem investimento direto do estado para a produção de filmes. Em 2015, do total de filmes de longa-metragem produzidos no mundo, $92 \%$ foram produzidos em países com investimento direto do estado na produção cinematográfica nacional (UNESCO, 2018).

Como se pode constatar, as organizações estatais e instituições governamentais são decisivas para o financiamento da criação, produção, distribuição e exibição dos conteúdos cinematográficos nacionais, mesmo em países com forte tradição liberal, como os EUA. Há uma correlação direta entre a destinação de recursos financeiros através de fundos públicos para a criação e produção de filmes e a quantidade de filmes nacionais produzidos por ano (UNESCO, 2018). O estado e os órgão governamentais participam diretamente de todos os elos da cadeia produtiva do cinema, especialmente dos elos produção, distribuição e exibição, destinando créditos fiscais, desembolso direto ou financiamento subsidiado para as empresas de cinema - pequenas, médias e grandes produtoras. 
Gráfico 6 - Número de filmes de longa-metragem produzido por ano, nos 25 países produtores, por investimento direto na produção cinematográfica, 2015.

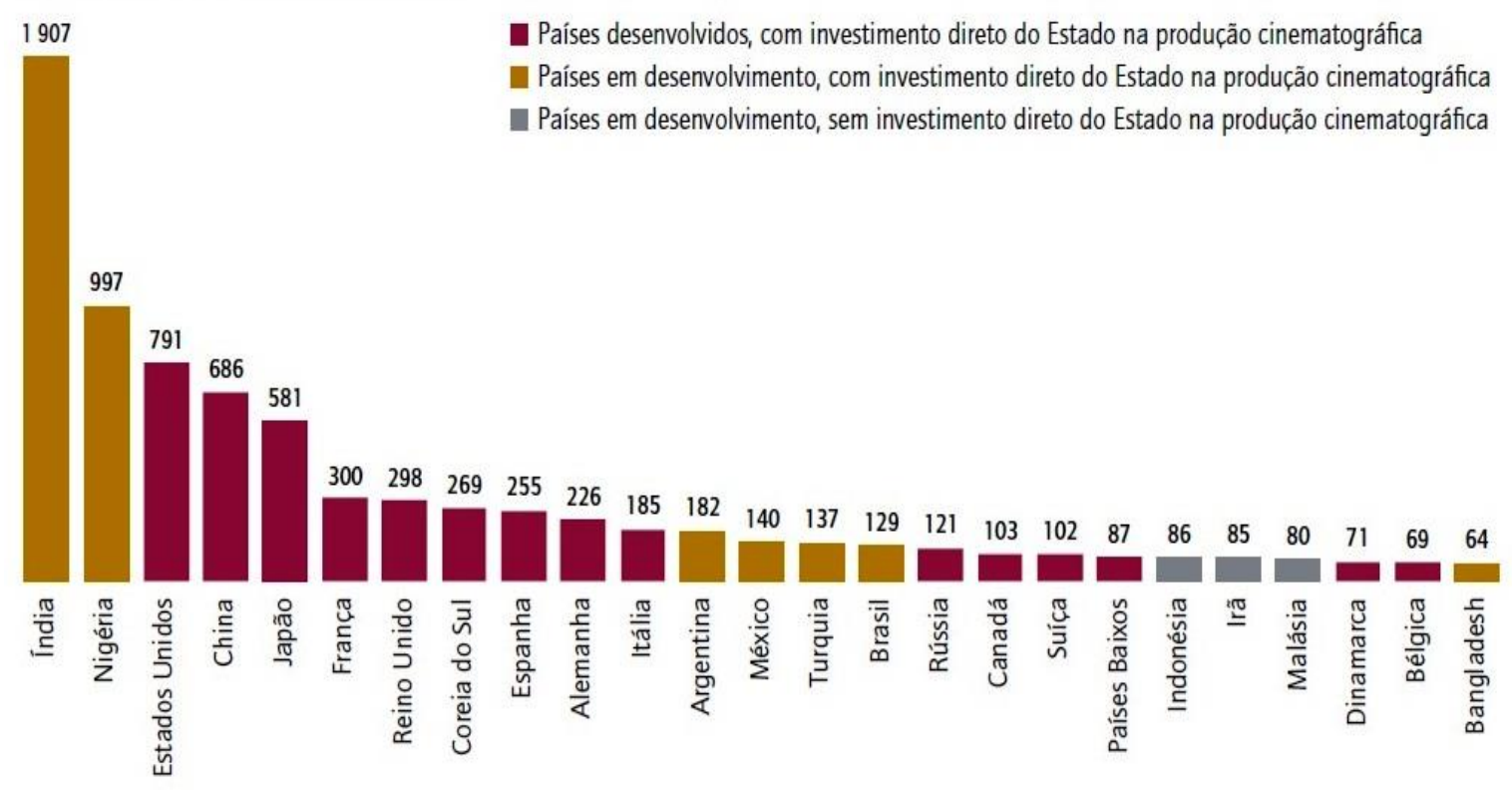

Fonte: UNESCO, 2018.

Com efeito, os governos nacionais atuam hoje como agentes financeiros e econômicos que dinamizam a competição e contribuem para a geração de novas formas de monetização entre os mercados cinematográficos internacionais. Essa atuação direta dos governos fez com que novas estratégias empresariais fossem adotadas tanto por parte de países desenvolvidos quanto por parte dos países em desenvolvimento. Não é por acaso que os governos nacionais têm se interessado em desenvolver as suas empresas para competirem nos seus mercados domésticos. Estamos falando de um contingente de bilhões de espectadores e de ingressos vendidos. Se somarmos apenas os públicos de China, México, Rússia, França e Brasil temos, em 2017, mais de 2,5 bilhões de espectadores. 
Tabela 4 - Público das salas de exibição em países selecionados (2017)

\begin{tabular}{c|c}
\hline País* & Público (em milhões) \\
\hline China & $1.620,0$ \\
\hline EUA & $1.216,8$ \\
\hline México & 338,0 \\
\hline Rússia & 212,2 \\
\hline França & 209,4 \\
\hline Brasil & 181,2 \\
\hline Japão & 174,5 \\
\hline Alemanha & 122,3 \\
\hline Espanha & 100,2 \\
\hline Australia & 85,0 \\
\hline Colômbia & 62,6 \\
\hline Argentina & 49,4 \\
\hline Chile & 27,6 \\
\hline Portugal & 15,6
\end{tabular}

Fonte: ANCINE, 2018.

Como consequência, a receita gerada, em 2017, pelos mercados selecionados nas tabelas 4 e 5 ultrapassa a quantia de US\$ 28 bilhões (cerca de R $\$ 90$ bilhões).

Tabela 5 - Renda das salas de exibição em países selecionados (2017)

\begin{tabular}{c|c} 
País* & $\begin{array}{c}\text { Renda (em milhöes de } \\
\text { dólares) }\end{array}$ \\
\hline EUA & $10.524,8$ \\
\hline China & $8.270,0$ \\
\hline Japão & $2.040,0$ \\
\hline França & $1.560,0$ \\
\hline Alemanha & $1.060,0$ \\
\hline Australia & 920,5 \\
\hline Rússia & 913,0 \\
\hline México & 853,5 \\
\hline Brasil & 851,5 \\
\hline Espanha & 676,8 \\
\hline Argentina & 292,5 \\
\hline Colômbia & 184,6 \\
\hline Chile & 136,7 \\
\hline Portugal & 92,3
\end{tabular}

Fonte: ANCINE, 2018.

Os países desenvolvidos possuem uma renda per capta superior aos países em desenvolvimento, o que permite que as famílias comprem mais ingressos, algo que se revela na disparidade do número de salas de cinema entre os dois blocos. No total, $79 \%$ das salas de cinema existentes no mundo estão localizadas nos países desenvolvidos e $21 \%$ nos países em desenvolvimento. Quando o dado se refere a outros locais de exibição/projeção, essa disparidade se reduz: 60\% dos locais destinados a 
exibição/projeção estão localizados em países em desenvolvidos e $40 \%$ em países em desenvolvimento (UNESCO, 2018). Dessa forma, a média de filmes recém-lançados exibidas em países desenvolvidos é bem superior àquela observada nos países em desenvolvimento.

Gráfico 7 - Média de filmes recém-lançados exibidos em países desenvolvidos e em desenvolvimento, 2005-2015

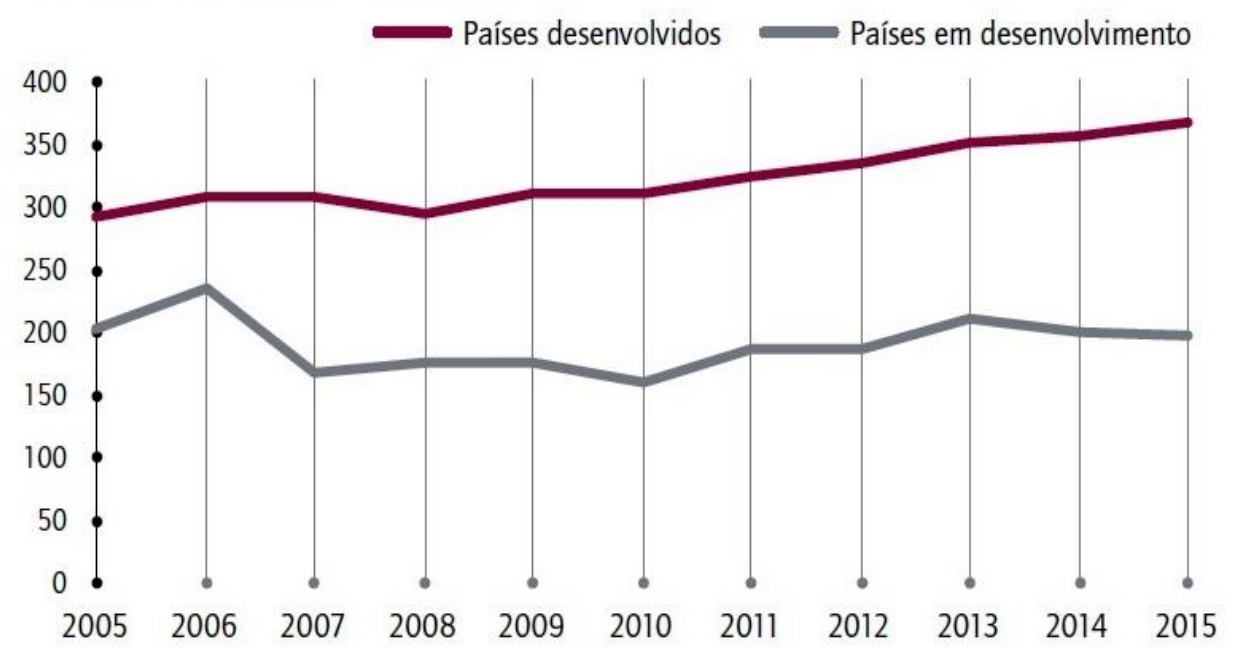

Fonte: UNESCO, 2018.

No entanto, o maior no número de salas de exibição entre 2009 e 2017 foi registrado entre os países em desenvolvimento. Durante esse período, a China registrou um crescimento de 975,1\% em seu parque exibido; a Rússia, um crescimento de 128\%; o Brasil, um crescimento de 52,7\%; o México, um crescimento de 82,5\%. Já entre os países desenvolvidos o crescimento foi bem menor ou registrou-se uma redução.

Tabela 6 - Quantidade de salas de exibição em países selecionados (2017)

\begin{tabular}{c|c|c} 
País* & Salas de Exibição & $\begin{array}{c}\text { Variação da } \\
\text { Quantidade de Salas } \\
2009-2017\end{array}$ \\
\hline China & 50.776 & $975,1 \%$ \\
\hline EUA & 40.393 & $-3,5 \%$ \\
\hline México & 6.633 & $48,1 \%$ \\
\hline França & 5.913 & $7,1 \%$ \\
\hline Alemanha & 4.803 & $1,5 \%$ \\
\hline Rússia & 4.793 & $128,0 \%$ \\
\hline Espanha & 3.625 & $-11,2 \%$ \\
\hline Japão & 3.525 & $3,8 \%$ \\
\hline Brasil & 3.223 & $52,7 \%$ \\
\hline Australia & 2.210 & $11,1 \%$ \\
\hline Colômbia & 1.082 & $82,5 \%$ \\
\hline Argentina & 963 & $8,8 \%$ \\
\hline Portugal & 571 & $-1,0 \%$ \\
\hline Chile & 411 & $37,0 \%$
\end{tabular}

Fonte: ANCINE, 2018. 
Com o aumento da participação governamental/estatal dos países em desenvolvimento no financiamento dos conteúdos nacionais, como no caso da Índia, China, Coréia do Sul, Brasil, México, Turquia e Argentina, a participação média na venda de ingressos das produções cinematográficas nacionais dos países em desenvolvimento se elevaram bastante, superando inclusive a participação média dos países desenvolvidos.

Significa dois aspectos: 1) entre 2011 e 2105, os países em desenvolvimento aumentaram a sua participação média na venda de ingressos dos seus próprios filmes nos seus mercados domésticos, como ocorreu no caso brasileiro; 2) devido as políticas de financiamento dos conteúdos nacionais, os países desenvolvidos, especialmente os EUA, passaram a enfrentar mais dificuldade para competir com os filmes nacionais produzidos e distribuídos nos países em desenvolvimento. $\mathrm{O}$ aumento do financiamento público por parte dos governos nacionais dos países em desenvolvimento criou novas oportunidades para as empresas locais.

Gráfico 8 - Participação média das produções cinematográficas nacionais no número de ingressos, por países desenvolvidos e em desenvolvimento.

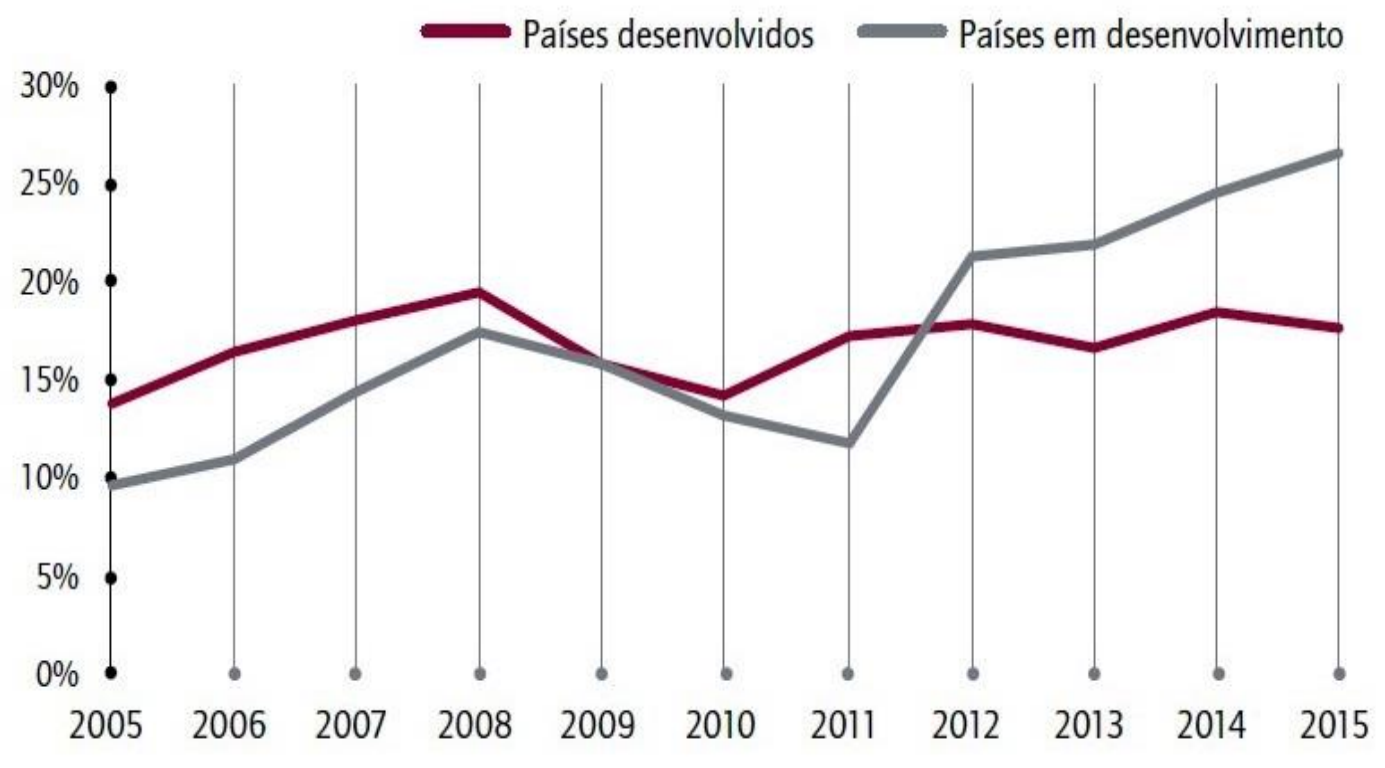

Fonte: UNESCO, 2018.

\section{O BRASIL FRENTE A COMPETIÇÃO CINEMATOGRÁFICA GLOBAL}

Desde a extinção da Empresa Brasileira de Filmes (EMBRAFILMES), em 1990, a principal política pública institucionalizada pelo Estado brasileiro para financiar as empresas produtoras, distribuidoras e exibidoras de cinema diz respeito ao Fundo Setorial do Audiovisual - FSA. O fundo foi criado em 2006, instituído como uma modalidade especifica do Fundo Nacional de Cultura (FNC). O FSA foi criado para dinamizar a cadeia produtiva dos conteúdos audiovisuais brasileiros - longasmetragens, séries, telefilmes, animação e games. Até 2011 o FSA obteve pouco impacto econômico no mercado de conteúdos audiovisuais brasileiros. Até esse último ano, duas modalidades de tributos 
carreavam recursos para o FSA, a Contribuição para o Desenvolvimento da Indústria cinematográfica Brasileira a partir das remessas (CODECINE Remessa) e a Contribuição para o Desenvolvimento da Indústria cinematográfica Brasileira a partir do número de títulos (CODECINE Títulos). Somados, até 2011, esses dois tributos não carrearam recursos suficientes para impactar o mercado de conteúdos audiovisuais brasileiros. A partir de 2011, com a aprovação da Lei nº12.485 (nova Lei da TV por assinatura) esses conteúdos experimentaram um grande crescimento. A referida lei criou um novo imposto, o CODECINE Teles, que passou a ser devida pelos prestadores de serviços que se utilizem de meios que possam distribuir conteúdos audiovisuais, tais como as empresas de telecomunicações (ANCINE, 2013). Com isso, as grandes operadoras de telefonia móvel e fixa que atuam no Brasil (TIM, OI, Vivo e Claro) passaram a pagar regularmente a CODECINE Teles.

O intenso aumento do consumo de conteúdos audiovisuais (especialmente séries, filmes e músicas) através dos aparelhos celulares móveis com acesso à internet, os smartphones, junto aos diferentes planos ofertados pelas operadoras de telefonia móvel, resultou num crescimento avassalador do consumo do audiovisual. Esse aspecto fez crescer sobremaneira a arrecadação do CODECINE Teles e, com isso, os recursos financeiros destinados para o FSA. Esse aspecto modificou todos os elos (produção, distribuição, exibição e consumo) do mercado de conteúdo audiovisuais brasileiros, pois o FSA passou a destinar recurso para o fortalecimento das empresas que atuam nesses elos. Em 2012, primeiro ano de funcionamento pleno da Lei $\mathrm{n}^{\mathrm{o}} 12.485$ e, por conseguinte, da nova modalidade de tributação, a CODECINE Teles, o FSA teve à sua disposição $R$ \$ 725 milhões, dos quais $\mathrm{R} \$ 655$ milhões foram decorrentes da arrecadação da CODECINE Teles, ou seja, 92\% de todos os recursos do FSA. Em 2015, com o aumento do fluxo de conteúdos digitais via smartphones, o volume de arrecadação do FSA chegou a RS 1,1 bilhões, dos quais 90\% decorrentes da arrecadação da CODECINE Teles.

Tabela 4 -CODECINE- valores arrecadados entre 2010/2016

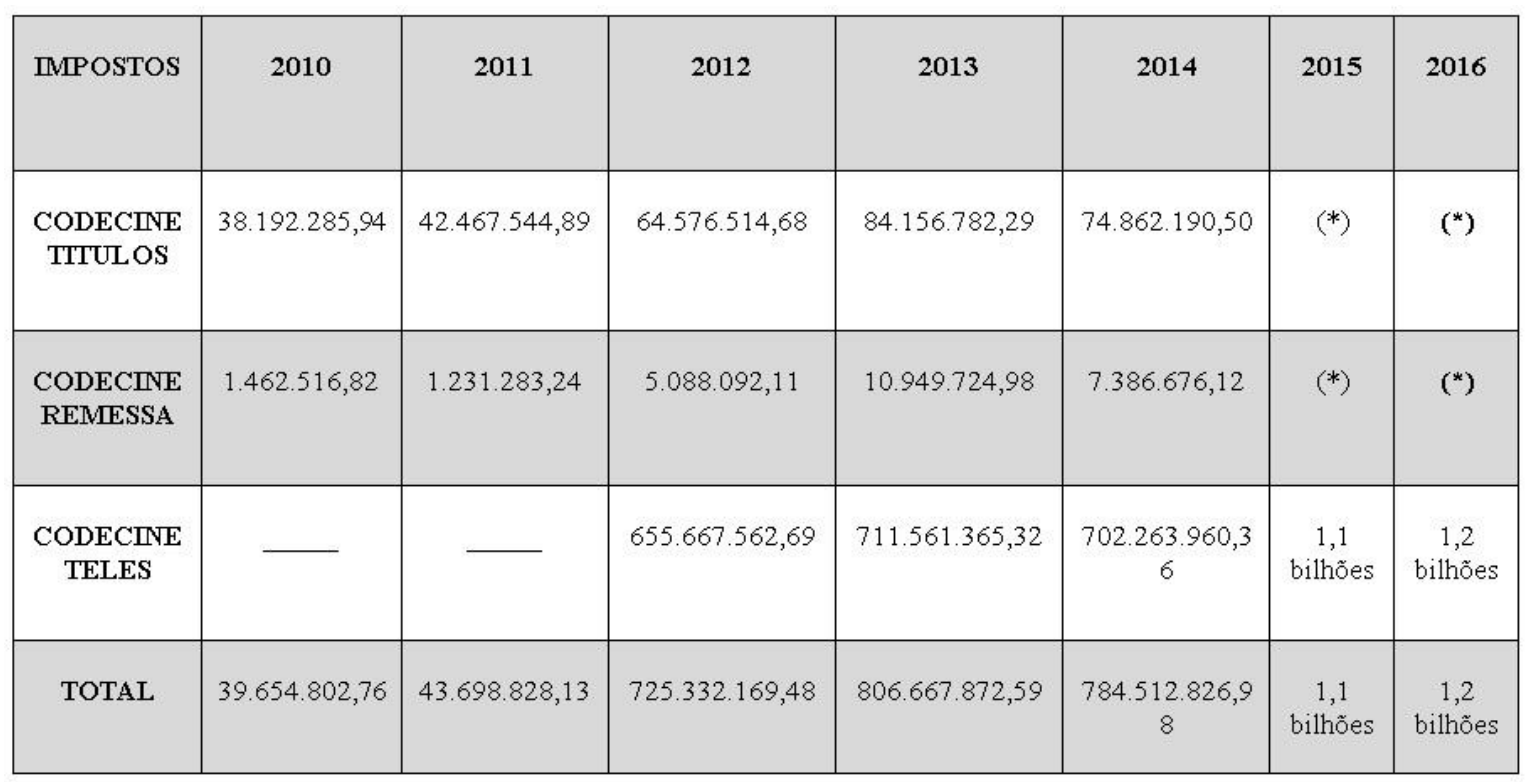

Fonte: ANCINE, 2017. 
Esses recursos foram destinados ao principal gestor financeiro do FSA, o Banco Nacional de Desenvolvimento Econômico e Social (BNDES), e, com efeito, emprestado, a juros bastante módicos, às empresas brasileiras especializadas na produção, distribuição e exibição de conteúdos audiovisuais brasileiros. A dinâmica econômica e financeira de arrecadação da CODECONE Teles acontece da seguinte forma. $\mathrm{O}$ fato gerador é a oferta e o uso de pacotes de telefonia celular para os consumidores por parte das companhias de telefonia móvel. Uma vez distribuídos e consumidos os conteúdos digitais-culturais (áudio, fotografias, séries, filmes, games, entre outros), as empresas pagam - todo dia 31 de março de cada exercício - a CODECINE Teles. O valor arrecadadoé repassado para o FSA, que tem como principal gestor a Agência Nacional de Cinema - ANCINE. Essa, por sua vez, repassa os recursos para o principal agente financeiro do fundo, o Banco Nacional de Desenvolvimento Econômico e Social (o BNDES), que, mediante editais específicos e através do fluxo contínuo, repassa os recursos, na forma de empréstimos, para as empresas brasileiras de produção, distribuição e exibição de conteúdos audiovisuais nacionais.

Figura 4 - dinâmica de arrecadação e repasse financeiro do FSA - serviços culturais-digitais

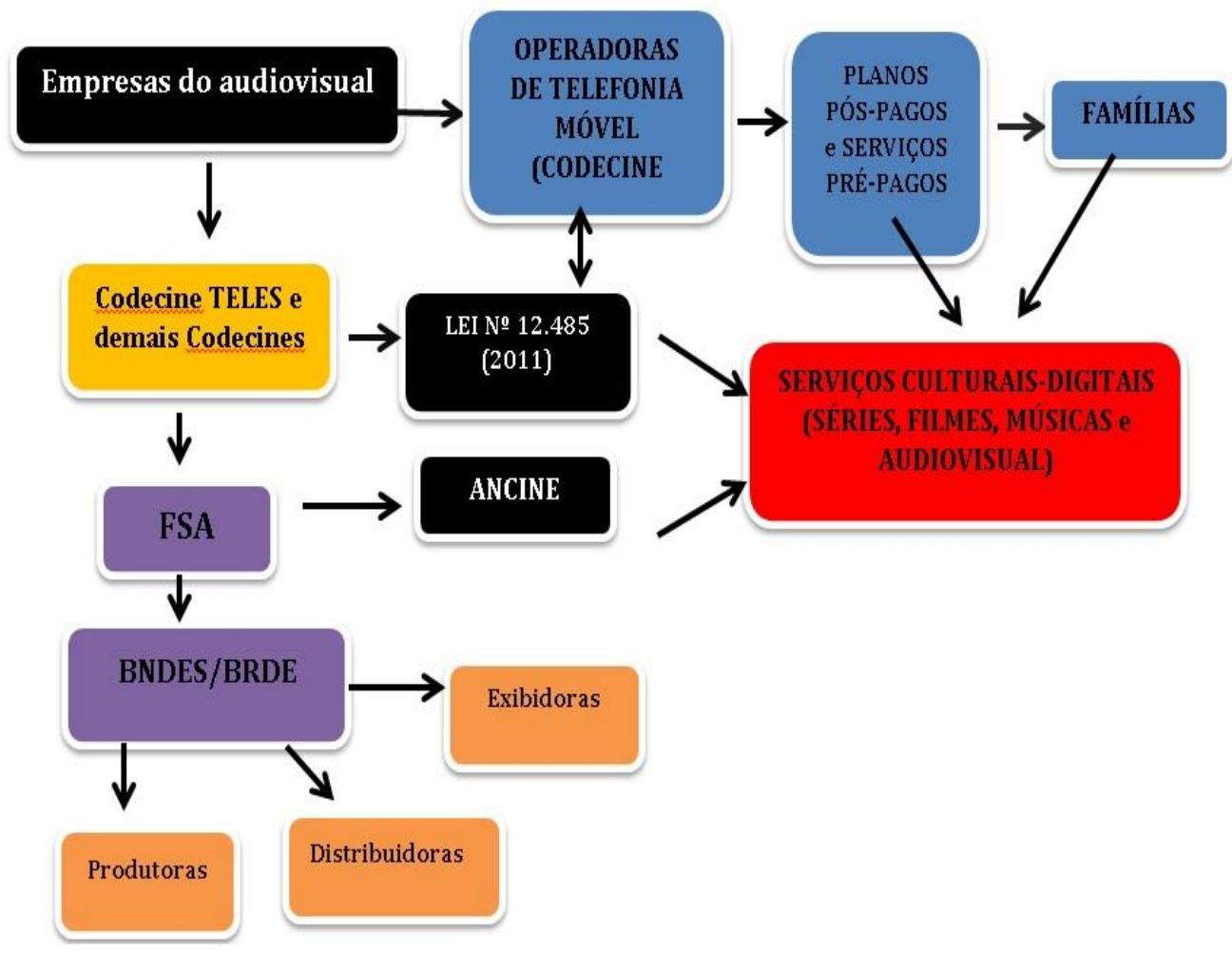

Fonte: elaboração do autor.

Em 2012, primeiro ano de funcionamento pleno do FSA, foram produzidos 83 longasmetragens nacionais; quatro anos mais tarde, em 2016, foram 142, crescimento de $70 \%$ em apenas quatro anos. Em 2009, 61,9\% dos títulos brasileiros (principalmente longas metragens) foram distribuídos por empresas com origem e sede do capital localizada no exterior, principalmente os principais estúdios de produção e distribuição norte-americanos. Em 2015, 
seis anos depois, apenas $7 \%$ dos títulos nacionais foram distribuídos por empresas sediadas no exterior, sendo que $93 \%$ dos títulos nacionais foram distribuídos por empresas brasileiras.

Gráfico 9- Longas - metragens brasileiros lançados 1995-2016.

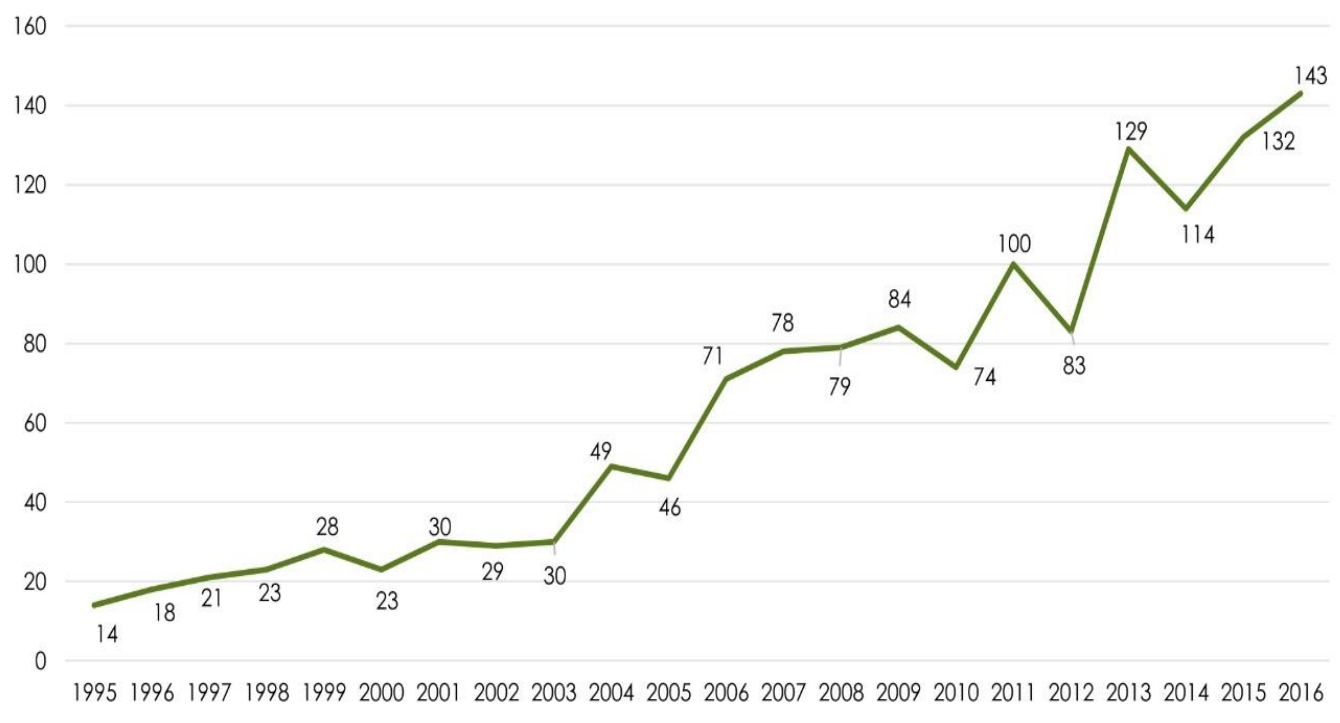

Fonte: ANCINE, 2017.

Parte significativa dos recursos arrecadados com o FSA foi destinada ao programa Brasil de Todas as Telas, destinado a empresar recursos para as principais empresas que compõem o parque exibidor brasileiro com vista à construção de salas de cinema, notadamente nos shoppings centers. Em 1975, o Brasil possuía um parque exibidor composto por 3.276 salas, maior número registrado desde então. No final de 2017, o parque exibidor brasileiro alcançou o total de 3.220 salas, $92 \%$ localizadas nos shoppings centers. Nos últimos cinco anos os recursos do FSA disponibilizados para o Programa Brasil de Todas as Telas contribuíram bastante para se alcançar esse número.

Gráfico 10- Expansão de salas de cinema no Brasil - 1971 - 2017

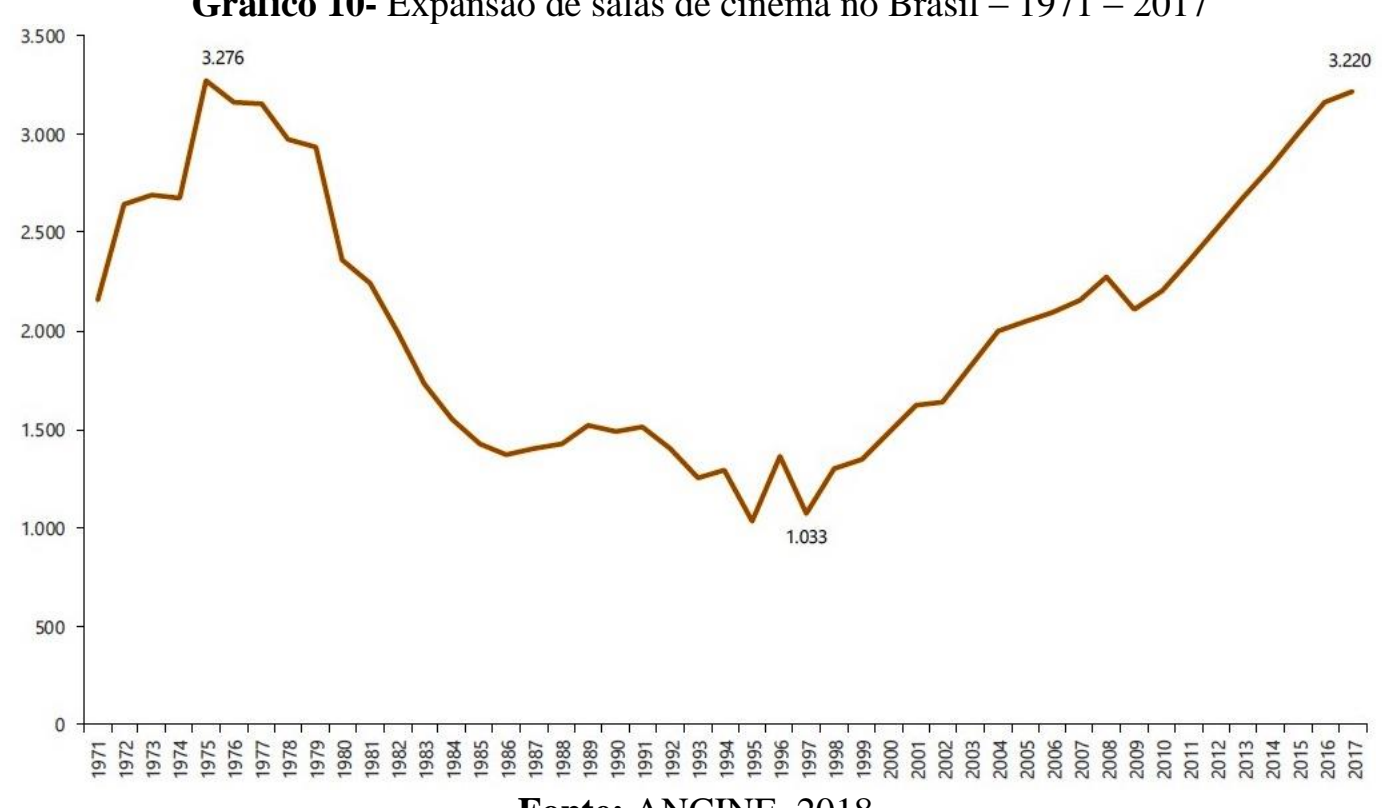

Fonte: ANCINE, 2018. 
Somados esses aspectos contribuíram para que os longas-metragens brasileiros enfrentassem parte da concorrência dos longas-metragens norte-americanos. Mesmo com a severa recessão econômica ocorrida em 2015 e 2016, acompanhada de uma forte redução do consumo das famílias brasileiras (redução de 3,2\% em 2014 e 4,3\% em 2016 ${ }^{1}$ ), o total de consumidores nas salas de cinema no Brasil obteve uma forte elevação na série histórica entre 2010 e 2017. Saindo, em 2010, de 134,8 milhões de ingressos vendidos para 181,2 milhões de ingressos, em 2017; sendo que, de 2015 para 2016, pináculo da recessão no Brasil, o crescimento foi de $6,5 \%$, saindo de 173 milhões de ingressos para 184,3 milhões.

Gráfico 11-Público total em salas de cinema (2009 a 2017)

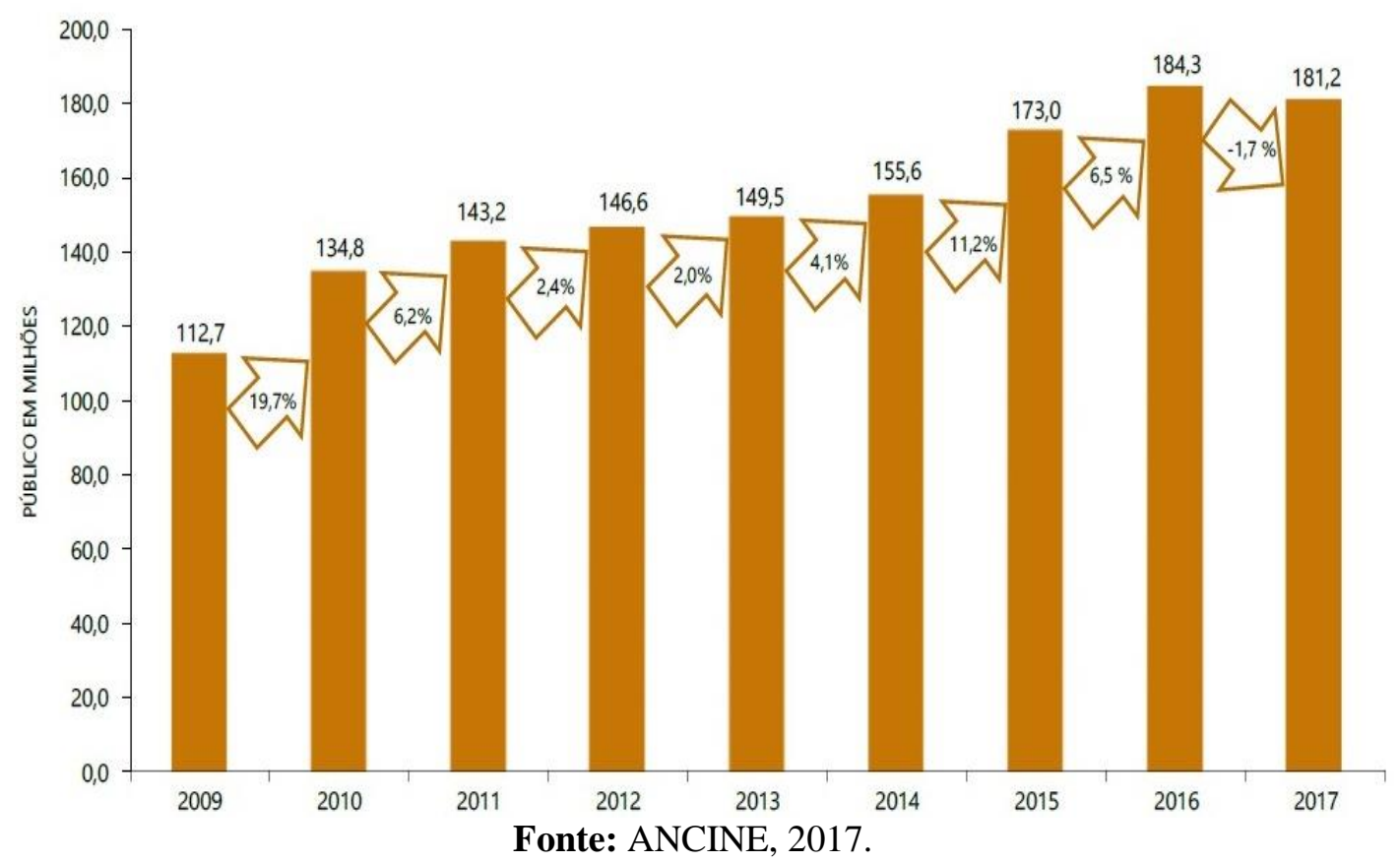

Mesmo diante do crescimento na venda de ingressos para o cinema no Brasil e, principalmente, em face da decisiva atuação do FSA, a participação de mercado (marketshare) dos longas-metragens brasileiros oscilou, chegando a 19,1\% (25,7 milhões de ingressos vendidos) em 2010, recuando para 10,7\% (15,7 milhões de ingressos) em 2012, voltando a subir para 16,5\% (30,4 milhões de ingressos) em 2015, voltando novamente a recuar para 9,6 (17,4 milhões de ingressos) em 2016. Mesmo em face de tais oscilações, resultado da voraz competição global pelo controle da produção, distribuição e exibição de conteúdos cinematográficos, é possível sustentar, sem embargo, que o mercado de conteúdos audiovisuais brasileiros hoje (nos seus seis vetores) é financiado pela expansãodos serviços culturais-digitais no país e, por conseguinte, pelo processo de rápida digitalização do simbólico.

${ }^{1}$ IBGE, 2017. 


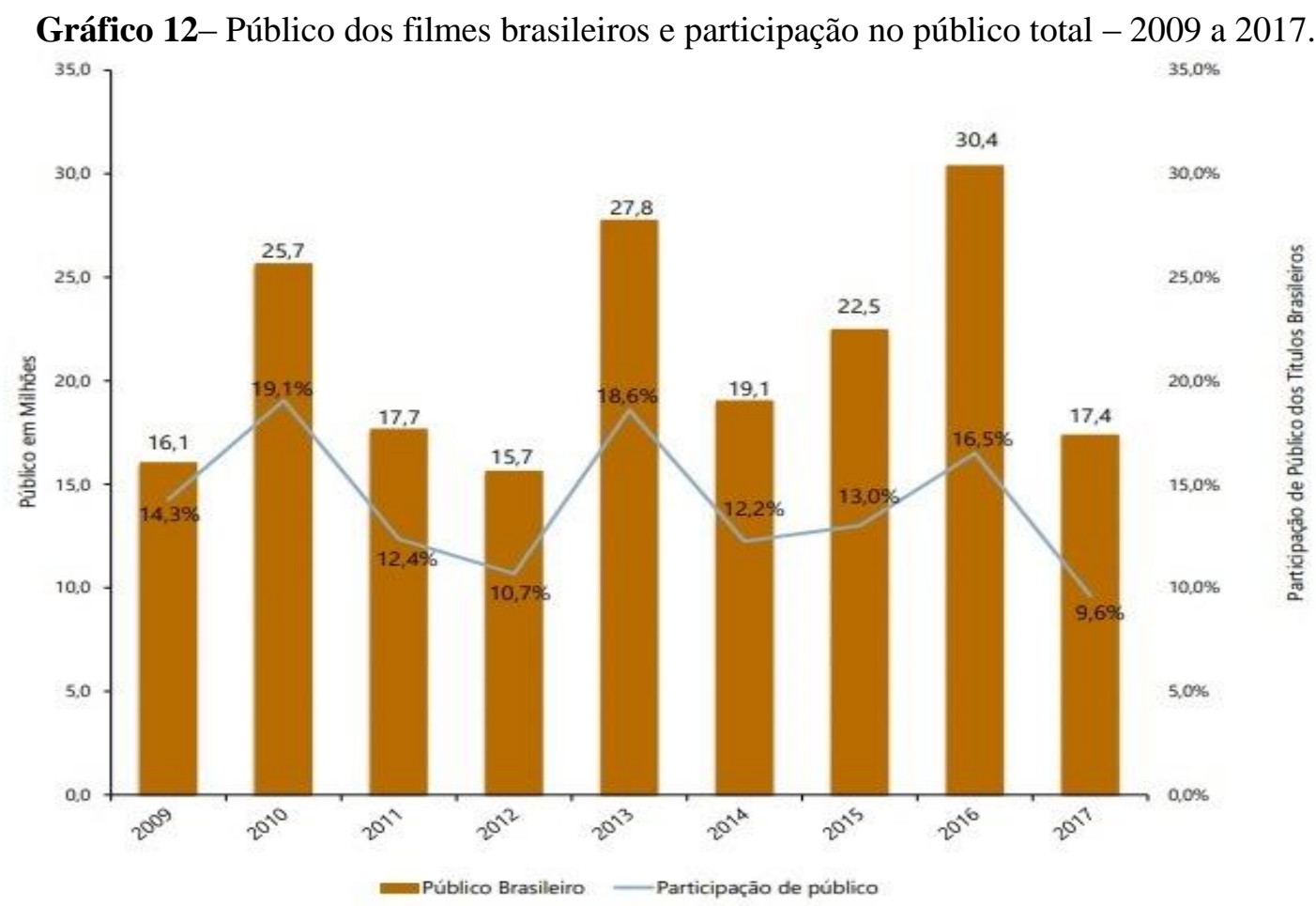

Fonte: ANCINE, 2017.

\section{CONSIDERAÇÕES FINAIS}

As três partes que compõem este artigo estão inteiramente interligadas. Demostram que, dificilmente, sem uma das dimensões do processo de digitalização do simbólico, a expansão do uso dos smartphones e do consumo dos conteúdos audiovisuais por meio desses aparelhos, existiria, com tamanha relevância econômica, o ecossistema de financiamento construído em torno do Fundo Setorial do Audiovisual (FSA).

Significa que, além de os mercados que compõem a economia do audiovisual estarem profundamente interdependentes, os mecanismos públicos de financiamento, principalmente os fundos, são criados e implementados dentro da própria economia do audiovisual e partir de frentes de expansão do consumo, como a internet. Esse exemplo se aplica a diversos outros países, como China, Índia e Coréia do Sul.

Todavia, no caso brasileiro, as pressões internas, exercidas, por exemplo, pelas empresas de telefonia celular móvel, assim como as pressões externas, exercidas, por exemplo, pelo governo dos EUA, podem comprometer a existência desse ecossistema.

Em outra frente, mais propriamente metodológica, não se pode compreender esses ecossistemas de financiamento, no Brasil e em diversos lugares do mundo, sem uma descrição precisa e cara da economia do audiovisual, especialmente do mercado cinematográfico. Esse foi 
o nosso principal propósito aqui, qual seja, fornecer um guia empírico-descritivo sobre esse intrincado labirinto econômico.

\section{REFERÊNCIAS BIBLIOGRÁFICAS}

Agência Nacional de Cinema (ANCINE). Relatório Anual de Gestão do Fundo Setorial do Audiovisual - Exercício 2016. Rio de Janeiro, 2017.

Panorama do VoD no Brasil.Perspectiva do VoD no Brasil e no mundo. SILVA, Ruana Maíra Alves Rufino, 2018.

Comitê Gestor de Internet no Brasil. Pesquisa sobre os usos das tecnologias de informação e comunicação nos domicílios brasileiros - Tic domicílios. São Paulo, 2018.

ALVES, Elder P. Maia. A expansão do mercado de conteúdos audiovisuais brasileiros: a centralidade dos agentes estatais de mercado - o FSA, a ANCINE e o BNDES. Caderno CRH (UFBA. Impresso), v. 30, p. 477-494, 2016.

Capitalismo cultural-digital: investimentos públicos versos incentivos fiscais. Revista do Observatório Itaú Cultura. São Paulo, 2017.

GRANOVETTE, Mark. The sociologyofeconomicslife.KoboEditions, Montreal, 2018.

MARTEL, Frederic. Smart: o que você não sabe sobre a internet. Rio de Janeiro, Civilização Brasileira, 2015.

FIRJAN. Mapeamento da Indústria criativa no Brasil. Rio de Janeiro, 2016.

IBGE. Acesso à internet e a televisão e posse de telefone móvel para uso pessoal. PNAD, Rio de Janeiro, 2016.

Instituto de Pesquisa Econômica Aplicada - IPEA. Panorama da Economia Criativa no Brasil. Rio de Janeiro, 2013.

UNESCO. Cultural times. The first global map of cultural and creative industries.Paris, 2015.

Repensar as políticas culturais. Criatividade para o desenvolvimento. Paris, 2018.

UNCTAD.Creative economy outlook. Trends in international trade in criativeindustriel.New York, 2018. 